\title{
Review Article \\ Phototreatment of Water by Organic Photosensitizers and Comparison with Inorganic Semiconductors
}

\author{
Merlyn Thandu, Clara Comuzzi, and Daniele Goi \\ Department of Chemistry, Physics and Environment, University of Udine, Via del Cotonificio 108, 33100 Udine, Italy \\ Correspondence should be addressed to Merlyn Thandu; merlyn.thandu@uniud.it
}

Received 12 November 2014; Revised 9 February 2015; Accepted 13 March 2015

Academic Editor: Maria da Graça P. Neves

Copyright (c) 2015 Merlyn Thandu et al. This is an open access article distributed under the Creative Commons Attribution License, which permits unrestricted use, distribution, and reproduction in any medium, provided the original work is properly cited.

\begin{abstract}
Phototreatment of water is drawing the attention of many as a promising alternative to replace methods like chlorination, ozonization, and other oxidation processes, used in current disinfection methods limiting harmful side-products and by-products that can cause damage to the fauna and flora. Porphyrins, phthalocyanines, and other related organic dyes are well known for their use in photodynamic therapy (PDT). These photosensitizers cause cell death by generating reactive oxygen species (ROS) especially singlet oxygen in the presence of light. Such molecules are also being explored for photodynamically treating microbial infections, killing of unwanted pathogens in the environment, and oxidation of chemical pollutants. The process of photosensitisation (phototreatment) can be applied for obtaining clean, microbe-free water, thus exploiting the versatile properties of photosensitizers. This review collects the various attempts carried out for phototreatment of water using organic photosensitizers. For comparison, some reports of semiconductors (especially $\mathrm{TiO}_{2}$ ) used in photocatalytic treatment of water are also mentioned.
\end{abstract}

\section{Introduction}

The fast and rapid growth of unwanted microbes distributed far and wide in the environment poses a threat to human health and other animals. These unwanted and harmful microbes grow and multiply in air, soil, and water causing both environmental and health hazards. Waterborne diseases alone account for millions of deaths annually worldwide [1]. Waterborne transmission of parasitic protozoa has caused the eruption of almost two hundred human diseases in a span of just 7 years (2004-2010) [2]. The fast growing global population and contamination of water resources by human activities and/or industries pose a challenge in achieving clean, microbe-free water for drinking and other domestic purposes. Scientists worldwide believe that waterborne diseases are affecting both the developed and the developing nations [1-4]. Acquiring pure water free of contaminants and pathogens is a matter of concern which calls for new, effective, and low cost water disinfection techniques.

Conventional disinfection mainly involves chlorination or ozonization. Another cheap alternative for disinfection is using direct sunlight (SODIS) (solar disinfection) [4]. But these methods face limitations like production of harmful by-products, involving high cost, limited water volume, and time consuming. In order to overcome these inadequacies, remarkable efforts have been carried out to develop more effective water disinfection methods than the conventional systems that are environment friendly, cost effective, and highly efficient [1-6].

Photocatalytic disinfection of water is gaining much interest as it involves three components that are individually harmless to the biological environment, namely, the photosensitizer, light, and molecular oxygen [7].

Some organic and inorganic catalysts on light irradiation in presence of oxygen produce reactive oxygen species (ROS) like singlet oxygen and hydroxyl radical (superoxide anion) that are cytotoxic species and are capable of killing bacteria, fungi, and viruses $[1,5,6,8,9]$. Not only disinfection but also these ROS can cause the oxidation of unwanted contaminants present in water, thereby carrying out dual function of disinfection and decontamination [1, 10-12]. Organic dyes like methylene blue, rose bengal, porphyrins, and phthalocyanines are used as photosensitizers $[5,8,12]$ for water disinfection while common inorganic catalysts are 
TABLE 1: Band-gap of some inorganic semiconductors [13, 14].

\begin{tabular}{lcccccc}
\hline Semiconductors & $\mathrm{TiO}_{2}$ (anatase) & $\mathrm{TiO}_{2}$ (rutile) & $\mathrm{ZnO}$ & $\mathrm{SnO}_{2}$ & $\mathrm{WO}_{3}$ & $\mathrm{ZnS}$ \\
\hline $\mathrm{Eg}(\mathrm{eV})$ & 3.2 & 3.0 & 3.2 & 3.9 & 2.8 & 3.7 \\
\hline
\end{tabular}

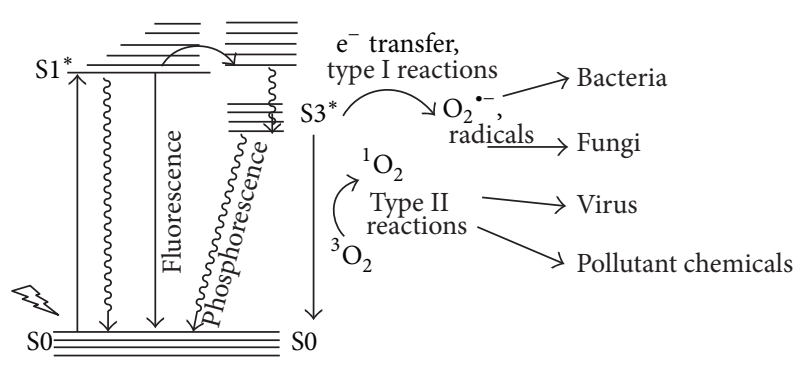

Figure 1: The Jablonski diagram.

$\mathrm{TiO}_{2}, \mathrm{ZnO}, \mathrm{ZnS}, \mathrm{CdS}, \mathrm{Fe}_{2} \mathrm{O}_{3}$, and $\mathrm{WO}_{3}[1,8,13,14]$. Among the inorganic semiconductors, $\mathrm{TiO}_{2}$ is the most widely used in photocatalysis. In this review, the wide ranges of organic photosensitizers available for photodynamic purification of water are outlined and their photosensitizing efficiencies are compared with those of semiconductor photocatalysis (mainly $\mathrm{TiO}_{2}$ ). Semiconductor photocatalysis in water purification is studied widely and some pilot plant experiments are conducted although large-scale applications for water treatment are still not in practice. Numerous reviews on semiconductor photocatalysis, their construction, modification, mechanisms, and modeling are reported in the literature $[1,6,7,15,16]$ and their repetition or replication is not the aim of this paper.

As a practice, it is found in the literature that the term photosensitizer is generally used for organic catalyst whereas inorganic catalysts are termed as photocatalyst. But, the term photocatalyst has been also used for organic compounds and vice versa in some instances $[17,18]$. For simplicity, organic catalyst will be termed as photosensitizers and inorganic catalyst as photocatalysts throughout this paper. However, there is no rule stating this differentiation.

\section{What Is Photosensitization/Photocatalysis?}

Photosensitization process principally involves three components, namely, the photosensitizer, light, and oxygen. On illumination at appropriate wavelength, the photosensitizer transfers its energy to molecular oxygen giving rise to reactive oxygen species (ROS) [6, 8, 19-21]. ROS are cytotoxic in nature which enables us to employ this phenomenon in destroying unwanted microorganisms like bacteria, fungi, and viruses (Figure 1). These ROS are also capable of oxidizing organic pollutants into $\mathrm{CO}_{2}$ and water [15].

Depending on the nature of photosensitizer/photocatalyst, the photodynamic action proceeds through type I or type II mechanism or both. Type I mechanism involves electron transfer from excited sensitizer to substrate molecule or oxygen yielding free radicals and superoxide ion whereas in type II mechanism, energy transfer between photosensitizer and oxygen produces singlet oxygen [8].

2.1. Visible Light Photodisinfection. Organic dyes and photosensitizers are generally absorbed in the visible range (400$800 \mathrm{~nm}$ ) and excitation is achieved by one photon transition $(h v)$ from the ground state (S0) to singlet excited state $\left(\mathrm{S} 1^{*}\right)$ (1). $\left(\mathrm{S} 1^{*}\right)$ can undergo intersystem crossing (ISC) to give the triplet excited state $\left(\mathrm{S} 3^{*}\right)(2)$. The relaxation of $\left(\mathrm{S}^{*}\right)$ and $\left(\mathrm{S}^{*}\right)$ to ground state results in fluorescence and phosphorescence, respectively $[8,21]((3)$ and (4)). Alternatively, since $\left(\mathrm{S}^{*}\right)$ has a longer lifetime than $\left(\mathrm{S}^{*}\right)$, it can also undergo radiationless transition by transferring its energy to another molecule [21]. In presence of oxygen, the photosensitizer easily transfers energy to triplet ground state oxygen via type II mechanism producing singlet oxygen ${ }^{1} \mathrm{O}_{2}(5)$ :

$$
\begin{gathered}
\mathrm{S} 0+h v \longrightarrow \mathrm{S}^{*} \\
\text { Intersystem crossing (ISC) } \mathrm{S}^{*} \longrightarrow \mathrm{S}^{*} \\
\text { Relaxation } \mathrm{S}^{*} \longrightarrow \mathrm{S} 0+h \nu \text { (fluorescence) } \\
\mathrm{S}^{*} \longrightarrow \mathrm{S} 0+h \nu(\text { Phosphorescence) } \\
\text { Or energy transfer S3 }{ }^{*}+{ }^{3} \mathrm{O}_{2} \longrightarrow \mathrm{S} 0+{ }^{1} \mathrm{O}_{2} \\
\text { Electron transfer } \mathrm{S}^{*}+\mathrm{O}_{2} \longrightarrow \mathrm{S}^{\bullet+}+\mathrm{O}_{2}{ }^{\cdot-}
\end{gathered}
$$

It is considered that photodamage to cell is predominantly caused by singlet oxygen via type II reactions [22, 23], but it is also proved that photosensitized action is caused by both type I and type II pathways [24, 25]. Ergaieg et al. [24] have reported that type I reactions had a significant role in inactivation of Gram-negative bacteria whereas the photoinactivation rate of Gram-positive bacteria was unchanged even in the absence of superoxide anion. Silva et al. [26] also have considered the production of $\mathrm{O}_{2}{ }^{--}(6)$ and propose that it may be involved in PDT apoptosis.

2.2. UV Based Photodisinfection. Semiconductors such as $\mathrm{TiO}_{2}, \mathrm{Fe}_{2} \mathrm{O}_{3}, \mathrm{WO}_{3}, \mathrm{ZnO}$, and CdSe require light energy in the UV-A $(\lambda<400 \mathrm{~nm})$ range to carry out photochemical activity. Such molecules have a band gap between the valence band and conduction band which can be activated by light. The light energy to excite the valence electron must be higher or equal to the band gap. The band gaps of some semiconductors are listed in Table 1. The different band gaps also suggest the efficiency of the materials. The larger the band gap, the more the photocatalytic activity of the semiconductor [27].

The energy required for excitation of such electrons lies in the UV region $(\lambda<400 \mathrm{~nm})[1,15]$. On illumination with sufficient energy, one of the electrons from the valence 
band excites to the conduction band forming electron-hole pair. The photoreactions follow type I mechanism resulting in formation of radicals $((7)-(11))$. The electron-hole pair can oxidize water yielding $\mathrm{HO}^{\circ}$ radicals which are powerful oxidizing agents that cause oxidation of pollutants into $\mathrm{CO}_{2}$ and $\mathrm{H}_{2} \mathrm{O}((12)-(14))$. The electron in the conduction band can combine with oxygen to form superoxide radical anion $\mathrm{O}_{2}{ }^{--}$ which can react with $\mathrm{H}^{+}$to produce hydroperoxyl radical $\mathrm{HOO}^{\circ}$, further protonation of which gives $\mathrm{H}_{2} \mathrm{O}_{2}$. These ROS are responsible for the oxidative degradation of contaminants and disinfection. The generation of singlet oxygen by $\mathrm{TiO}_{2}$ has also been proved recently [28, 29]. Konaka et al. [29] have shown that ${ }^{1} \mathrm{O}_{2}$ is formed by direct photosensitization or by ion annihilation of $\mathrm{O}_{2}{ }^{--}((15)$ and (16)):

$$
\begin{gathered}
\mathrm{TiO}_{2}+h v \longrightarrow h_{\mathrm{VB}}{ }^{+}+\mathrm{e}_{\mathrm{CB}}{ }^{-} \\
h_{\mathrm{VB}}{ }^{+}+\mathrm{H}_{2} \mathrm{O} \longrightarrow \mathrm{HO}^{\bullet}+\mathrm{H}^{+} \\
\mathrm{e}_{\mathrm{CB}}{ }^{-}+\mathrm{O}_{2} \longrightarrow \mathrm{O}_{2}{ }^{--} \\
\mathrm{O}_{2}{ }^{--}+\mathrm{H}^{+} \longrightarrow \mathrm{HOO}^{\bullet} \\
\mathrm{HOO}^{\bullet}+\mathrm{HOO}^{\bullet} \longrightarrow \mathrm{H}_{2} \mathrm{O}_{2}+\mathrm{O}_{2} \\
\mathrm{HO}^{\bullet}+\text { pollutant } \longrightarrow \mathrm{CO}_{2}+\mathrm{H}_{2} \mathrm{O} \\
\mathrm{O}_{2}{ }^{--}+\text {pollutant } \longrightarrow \mathrm{CO}_{2}+\mathrm{H}_{2} \mathrm{O} \\
\mathrm{HOO}^{\bullet}+\text { pollutant } \longrightarrow \mathrm{CO}_{2}+\mathrm{H}_{2} \mathrm{O}^{\longrightarrow} \\
\text { Direct photosensitization } \mathrm{TiO}_{2}+\mathrm{O}_{2} \longrightarrow{ }^{1} \mathrm{O}_{2} \\
\text { Ion annihilation TiO }{ }^{+}+\mathrm{O}_{2}{ }^{\cdot-} \longrightarrow{ }^{1} \mathrm{O}_{2}
\end{gathered}
$$

\section{Photodisinfection Mechanism}

It has been known for almost a century that light and photosensitizer can cause destruction of microorganisms [5], and during these years many have discussed and some have put forward their results to explain the mechanism of cell killing $[9,16,25,30-38]$. The photoprocess successfully causes reduction in survival of bacteria (Gram-positive and Gramnegative), yeast, fungi, and viruses [32]. The accumulation of the photosensitizer in the bacteria was thought to be the prerequisite for its destruction [9]. Basically, two main approaches of photokilling were elucidated: (i) breaking of the cell membrane and its constituents and (ii) DNA damage. Many results have been put forward to prove that phototreatment induces alterations in the membrane as well as cell constituents. Depending upon the type of microorganism, the mechanism of photoinactivation and the cellular targets could vary as discussed in the following sections.

3.1. Bacteria. The photodynamic effect of TMPyP (Figure 2 displays the structure of different organic photosensitizers and the abbreviations are indicated in brackets) on four different E. coli strains $\left(\mathrm{O}_{4}\right.$, WP2 TM9, Bs-1, and TG1) was studied by Valduga et al. [39]. All the cell suspensions on photosensitization underwent about 5-log decrease in cell survival after $30 \mathrm{~min}$ irradiation. They observed alterations in the electrophoretic mobility of outer membrane proteins as well as cytoplasmic proteins. Lactate and NADH dehydrogenases were readily inactivated by irradiation in presence of TMPyP. Similarly, the activities ATPase and succinate hydrogenase were impaired. A decrease of plasmid DNA extracted from irradiated $E$. coli TG1 cells was also observed. Further, Bertoloni et al. [32] have studied the mechanism of photosensitizing activity of $\mathrm{Hp}$ on $\mathrm{S}$. aureus. Electrophoretic analysis of visible light irradiated $\mathrm{Hp}$ sensitized $S$. aureus shows that the photoprocess induces a modification consequent to protein-protein cross-linking formation at the level of cytoplasmic membrane proteins but not at the level of cytoplasmic proteins. But, changes in both plasmidial and chromosomal DNA strands were observed in both in vivo and in vitro photoprocesses at long irradiation time.

3.2. Fungi. Likewise, membrane and intracellular damage is caused by photosensitization of fungi as well. Lambrechts et al. [74] observed that, in dark conditions, the cationic porphyrin TriP4 binds to the cell envelope of Candida albicans and does not enter into the cell. Upon illumination, the cell membrane is damaged and becomes permeable for TriP4 and a lethal damage of the cell occurs. Cationic porphyrins interact strongly with DNA and cause photocleavage in solution [35]. Quiroga et al. [36] used TFAP ${ }^{3+}, \mathrm{TMAP}^{4+}$, and TMPyP to study the photoinactivation of C. albicans. All the cationic porphyrin exhibited a photosensitizing activity causing about 3.5-log decrease in cell survival. The interaction of the porphyrins with DNA was confirmed by the alterations in the spectral properties (mainly Soret band) of the porphyrins. However, their studies did not find any significant cleavage of isolated genomic DNA in C. albicans.

3.3. Protozoa. Ferro et al. [75] studied the inactivation of Acanthamoeba palestinensis (pathogenic protozoa) with photodynamic treatment with a tetra cationic $\mathrm{Zn}$ (II)-phthalocyanine (RLP068) and found that the survival of the cysts dropped down considerably. Further, the study on the mechanism of photosensitized inactivation of A. palestinensis [31] proved that the activities of mitochondrial enzymes (NADH, $\mathrm{SDH}$, and CS) showed no significant decrease, while that of cytoplasmic enzyme LDH was inhibited up to $35 \pm 4 \%$. Transmission electron microscope images of the trophozoites incubated with $2 \mu \mathrm{mol} \mathrm{L}^{-1}$ for $10 \mathrm{~min}$ and irradiated for $10 \mathrm{~min}$ at $500 \mathrm{Wm}^{-2}(600-700 \mathrm{~nm})$ showed several subcellular sites to be severely damaged. The cytoplasm was highly vacuolized and various vesicles surrounded by a membrane were visible while plasma and nuclear membranes were unchanged in comparison with control cells. Photoinactivation thus induces both functional damage and morphological damage to the microorganism resulting in its complete destruction.

There are numerous evidences for the interaction of photosensitizers with cell components and thereby their destruction in presence of light but cell death is not due to the alteration of intracellular components but the primary cause being the cell membrane and the cell wall. This is evident because $D$. radiodurans having very efficient DNA 
<smiles>[NH3+][OH+]c1c(I)cc2c(-c3c(Cl)c(Cl)c(Cl)c(Cl)c3C(=O)[O-])c3cc(I)c(=O)c(I)c-3oc2c1I</smiles>

Rose bengal (RB)<smiles>N#Cc1c2ccccc2c(C#N)c2c3ccc(C(=O)O)cc3c3ccccc3c12</smiles>

9,14-dicyanobenzo[b]triphenylene3-carboxylic acid (DBTP-COOH)<smiles>CN(C)c1ccc2nc3ccc(=[N+](C)C)cc-3sc2c1</smiles>

Methylene blue (MB)<smiles>O=C(O)c1cccc2c1C(=O)c1ccccc1C2=O</smiles>

9,10-anthraquinone4-carboxylic acid (ANT)

(a) Aromatic compounds

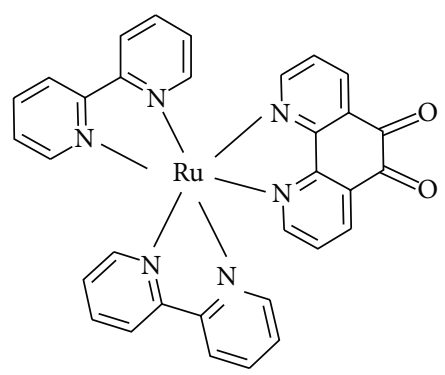

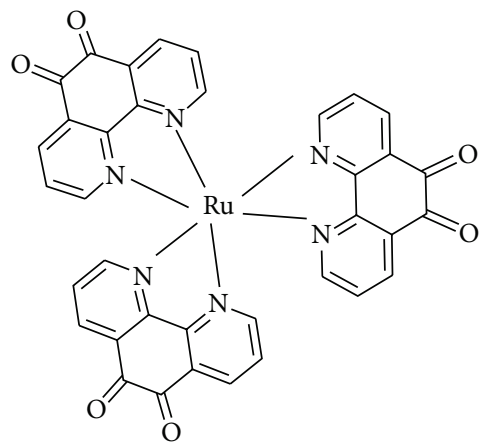

$\operatorname{Bis}\left(2,2^{\prime}\right.$-bipyridine)(1,10-phenanthroline-5,6-dione) ruthenium(II) (complex 1)

Tris(1,10-phenanthroline-5,6-dione) ruthenium(II) (complex 2)

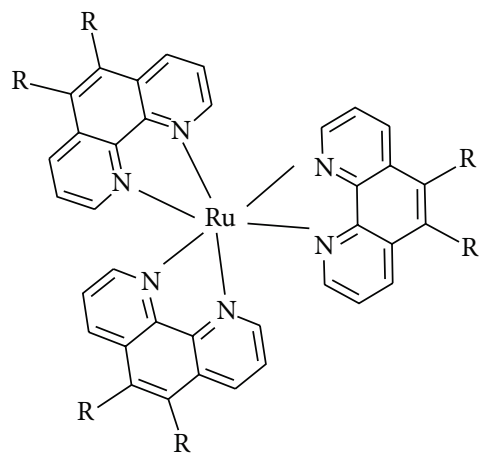

$\mathrm{R}=\mathrm{Tris}\left(4,7\right.$ diphenyl-1,10-phenanthroline)ruthenium $\left(\mathrm{RDP}^{2+}\right)$

$\mathrm{R}=\mathrm{C}_{9} \mathrm{H}_{19} \quad$ Tris(4,40-dinonyl-1,10-phenanthroline)ruthenium $(\mathrm{II})\left(\mathrm{RBN}^{2+}\right)$

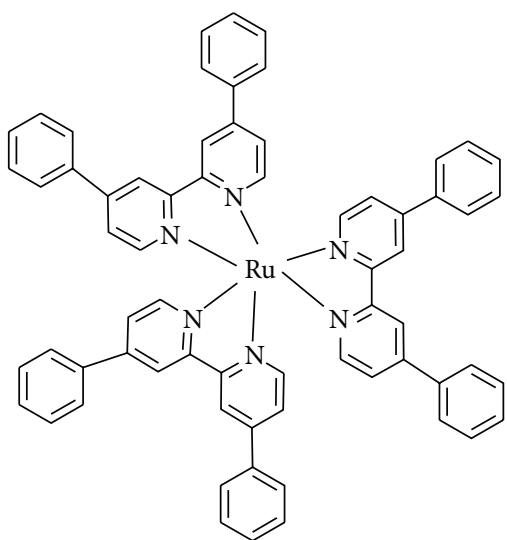

Tris $\left(4,4^{\prime}\right.$-diphenyl-2,2' -

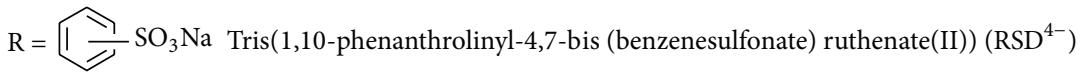

(b) Ruthenium complexes

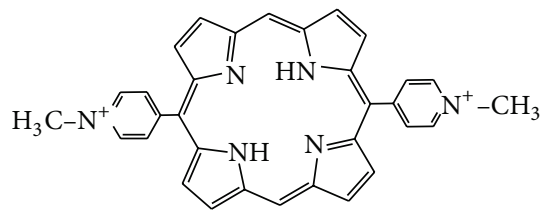

5,15-Di( $N$-methyl-4-pyridinium) porphyrin (DMPyP)

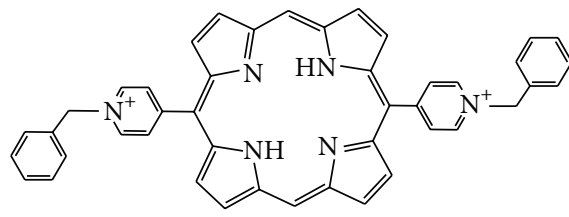

5,15-Di( $N$-benzyl-4-pyridinium) porphyrin (DBPyP)

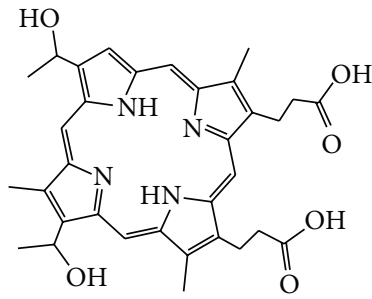

Hematoporphyrin (Hp)

FIGURE 2: Continued. 


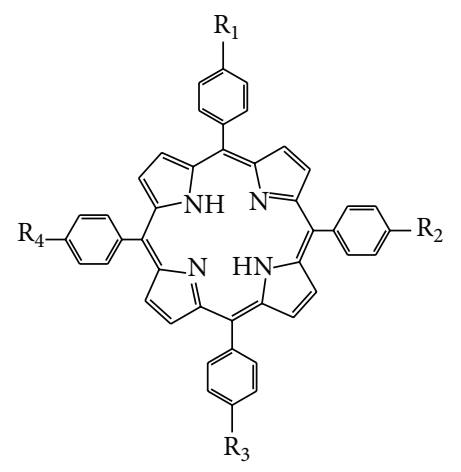

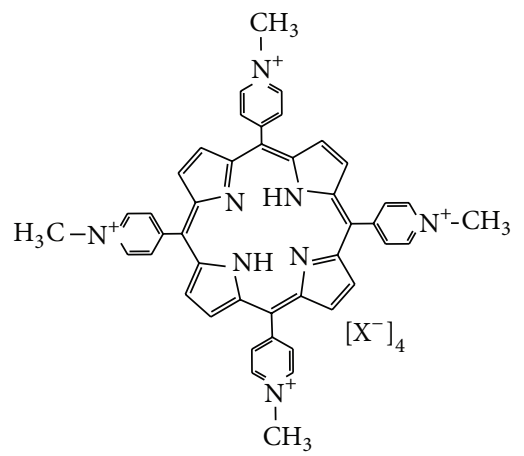

$$
\begin{aligned}
& \mathrm{R}_{1}=\mathrm{R}_{2}=\mathrm{R}_{3}=\mathrm{R}_{4}=\mathrm{A}=4 \text { - }\left(3-\mathrm{N}, \mathrm{N}, \mathrm{N} \text {-trimethylammoniumpropoxy)- } \mathrm{O}\left(\mathrm{CH}_{2}\right)_{3} \mathrm{~N}^{+}\left(\mathrm{CH}_{3}\right)_{3} \mathrm{I}^{-}\left(\mathrm{A}_{4}{ }^{4+}\right)\right. \\
& \mathrm{R}_{1}=\mathrm{R}_{3}=\mathrm{A} \\
& \mathrm{R}_{1}=\mathrm{A} \quad \mathrm{R}_{2}=\mathrm{R}_{3}=\mathrm{R}_{4}=\mathrm{B}\left(\mathrm{A}_{3} \mathrm{~B}^{+}\right)
\end{aligned}
$$

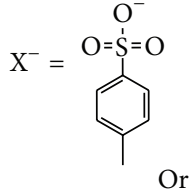<smiles>[R3]c1c2nc(c([R3])c3ccc([nH]3)c([R3])c3nc(c([R3])c4ccc1[nH]4)C=C3)C=C2</smiles><smiles>[R]=[R]=[R]</smiles><smiles>Fc1cc(F)c(F)c(F)c1F</smiles><smiles>[R]=[R]</smiles><smiles>[R][R]</smiles><smiles>CC</smiles><smiles>c1cc[nH+]cc1</smiles><smiles>Fc1cc(F)c(F)c(F)c1F</smiles><smiles>C1CCCCC1</smiles>

$$
\mathrm{R}_{1}=\mathrm{R}_{2}
$$

$$
\mathrm{R}_{3}=\mathrm{R}_{4}
$$<smiles>Fc1cc(F)c(F)c(F)c1F</smiles>

$\mathrm{R}_{1}$<smiles>[R]=[R]=[W]</smiles><smiles>Fc1cc(F)c(F)c(F)c1F</smiles>

$$
\mathrm{R}_{1}=\mathrm{R}_{2}=\mathrm{R}_{3}
$$<smiles>c1ccccc1</smiles>

$\mathrm{R}_{1}=\mathrm{R}_{2}=\mathrm{R}_{3}$
$\mathrm{R}_{4}$<smiles>Fc1cc(F)c(F)c(F)c1F</smiles>

5,10,15-tris(1-methylpyridinium-4-yl)-20-(pentafluorophenyl) porphyrin triiodide (Tri-Py $\left.{ }^{+}-\mathrm{Me}-\mathrm{PF}\right)$

5,15-bis(1-methylpyridinium-4-yl)-10,20-bis(pentafluorophenyl) porphyrin di-iodide $\left(\mathrm{Di}-\mathrm{Py}^{+}-\mathrm{Me}-\mathrm{PF}_{\mathrm{opp}}\right)$

5,10-bis(1-methylpyridinium-4-yl)-15,20-bis(pentafluorophenyl) porphyrin di-iodide $\left(\mathrm{Di}-\mathrm{Py}^{+}-\mathrm{Me}-\mathrm{PF}_{\mathrm{adj}}\right)$

5-(1-methylpyridinium-4-yl)-10,15,20-tris(pentafluorophenyl) porphyrin di-iodide (Mono-Py $\left.{ }^{+}-\mathrm{Me}-\mathrm{PF}\right)$

5-(pentafluorophenyl)-10,15,20-triphenylporphyrin (Tri-Ph-PF)

Tri-meso( $N$-methyl-pyridinium), meso( $N$-tetradecyl-pyridinium) porphine $\left(\right.$ Tri-Py $\left.{ }^{+}-\mathrm{Me}-\mathrm{PyTD}\right)$

Figure 2: Continued. 


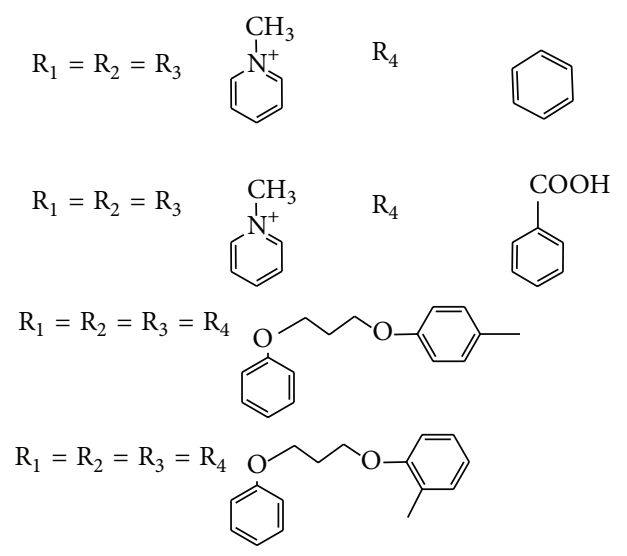

5-Phenyl-10,15,20-tris-( $N$-methylpyridinium-4-yl) porphyrin chloride (TriP4)

\author{
5-Carboxyphenyl-10,15,20-tris-( $N$-methylpyridinium-4-yl) \\ porphyrin triiodide (TriP4-COOH) \\ 5,10,15,20-tetra-[4-(3-phenoxy)-propoxy] phenyl porphyrin (H2Pp (a)) \\ 5,10,15,20-tetra-[2-(3-phenoxy)-propoxy] phenyl porphyrin (H2Pp (b))
}

(c) Porphyrins

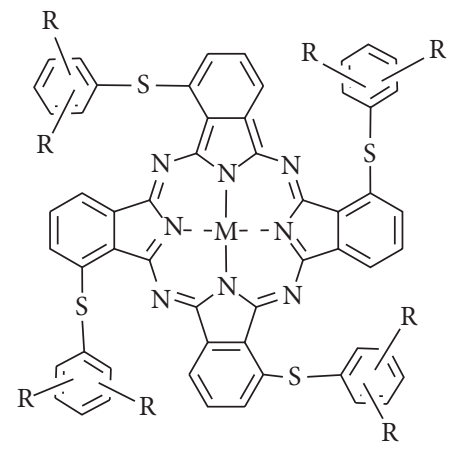

$\mathrm{M}=\mathrm{Zn}, \mathrm{R}=\mathrm{CH}_{2} \mathrm{Cl}$ 3-tetra[di(chloromethyl)phenylthio] phthalocyaninato

Zinc $\left(\mathrm{ZnPc}(\mathrm{Sph})_{4} \mathrm{Clm}_{8}\right)$ on silica $\left(\mathrm{D} / \mathrm{ZnClm}_{7}\right)$

$\mathrm{M}=\mathrm{Zn}, \mathrm{R}=\mathrm{CH}_{2}-\mathrm{N}^{+}\left(\mathrm{CH}_{3}\right)_{2}-\mathrm{CH}_{2} \mathrm{CH}_{2} \mathrm{OH}-3$-tetra[di(chloromethyl)phenylthio]

phthalocyaninato zinc hydroxide $\left(\mathrm{D} / \mathrm{ZnChol}_{7}\right)$

$\mathrm{M}=\mathrm{Al}, \mathrm{R}=\mathrm{CH}_{2} \mathrm{Cl}$ 3-tetra[di(chloromethyl)phenylthio] phthalocyaninato

Aluminium $\left(\mathrm{AlPc}(\mathrm{Sph})_{4} \mathrm{Clm}_{8}\right)$ on silica $\left(\mathrm{D} / \mathrm{AlClm}_{7}\right)$

$\mathrm{M}=\mathrm{Al}, \mathrm{R}=\mathrm{CH}_{2}-\mathrm{N}^{+}\left(\mathrm{CH}_{3}\right)_{2}-\mathrm{CH}_{2} \mathrm{CH}_{2} \mathrm{OH}$-3-tetra[di(chloromethyl)-phenylthio]

phthalocyaninato aluminium hydroxide $\left(\mathrm{D} / \mathrm{AlChol}_{7}\right)$

$\mathrm{M}=\mathrm{Al}, \mathrm{R}=\mathrm{CH}_{2}-\mathrm{NH}-\mathrm{CH}_{2} \mathrm{CH}_{2} \mathrm{SO}_{3}-\mathrm{Na}^{+}$-tetra[di(taurylmethyl)phenylthio]

phthalocyaninato (D/AlTaur 7 )

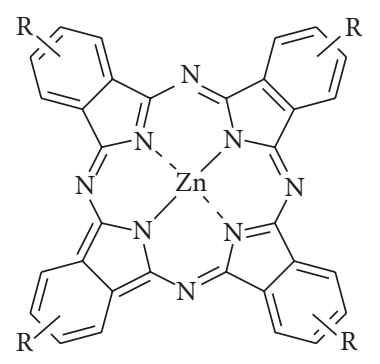

$\mathrm{R}=\mathrm{O}-{ }_{1-\mathrm{N}^{+}-}$

Zinc(II) 2,9,16,23-tetrakis [4-(N-methylpyridyloxy)] phthalocyanine $\left(\mathrm{ZnPPc}^{4+}\right)$

$\mathrm{R}=\mathrm{NO}_{2}$

Zinc(II) tetranitrophthalocyanine (ZnTNPc)

$\mathrm{R}=\mathrm{O}$

Zinc(II) tetra(phenyloxy)phthalocyanine (ZnTPhOPc)

$\mathrm{R}=\mathrm{O}_{\mathrm{I}^{-}}^{\mathrm{N}^{+}-}$

Zinc(II) tetra( $N, N, N$-trimethylaminoethyloxy) phthalocyaninate tetraiodide (ZnTTMAEOPcI)<smiles>[R]Oc1ccc([N+](C)(C)C)cc1</smiles>

1(4),8(11),15(18),22(25)-tetrakis-3-(N,N,N-trimethylammonium) phenoxy-phthalocyanine zinc(II) chloride (RLP068)

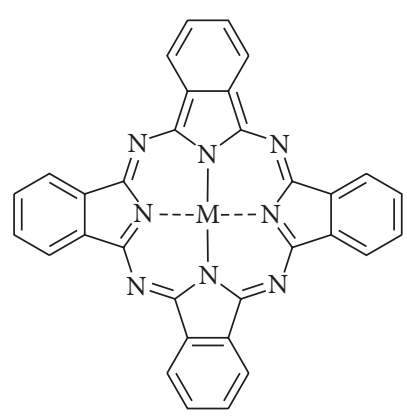

Phthalocyanine $=\mathrm{PCH}$

$\mathrm{M}=\mathrm{Ti}(\mathrm{TiPCH})$

$\mathrm{M}=\mathrm{Zn}(\mathrm{ZnPCH})$

$\mathrm{M}=\mathrm{Si}(\mathrm{SiPCH})$

$\mathrm{M}=\mathrm{Al}(\mathrm{AlPCH})$

$\mathrm{M}=\mathrm{Co}(\mathrm{CoPCH})$

$\mathrm{M}=\mathrm{Ni}(\mathrm{NiPCH})$

$\mathrm{M}=\mathrm{Cu}(\mathrm{CuPCH})$

Metal-free PCH (MeFPCH)

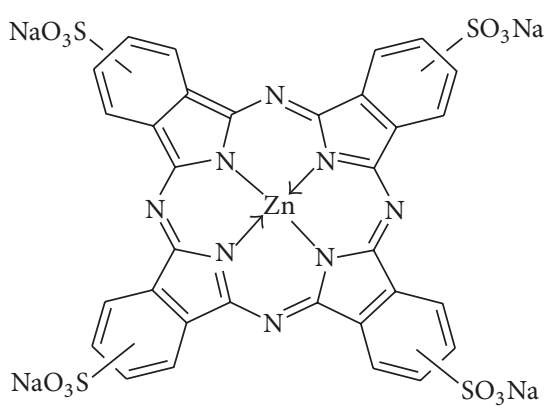

Zinc(II) phthalocyanine tetrasulfonic acid tetrasodium salt (ZnPcS)

(d) Phthalocyanines

Figure 2: Continued. 


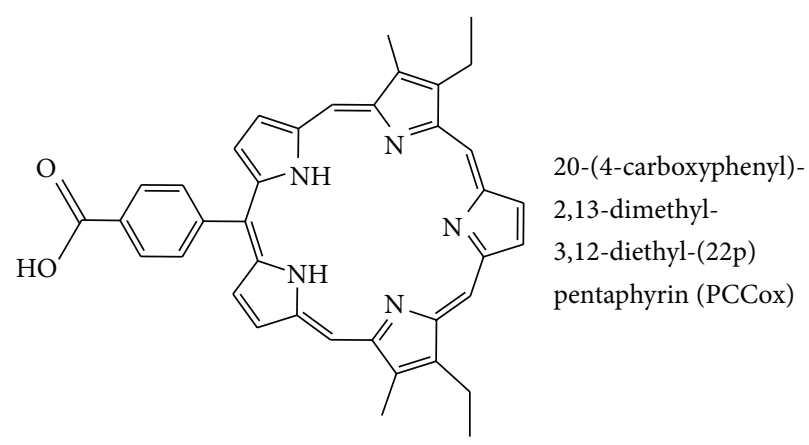

(e) Pentaphyrins

Figure 2: (a-e) Molecular structures, full names, and abbreviations of photosensitizers.

repair mechanism easily undergoes photosensitization [45, 63]. TMPyP-mediated photosensitization of $D$. radiodurans [76] revealed the leakage of potassium and magnesium from cells and a significant loss of phosphate which could be followed as a function of light dose. Thus, the cell wall is the primary target in photoinactivation and the destruction of intracellular components is the possible consequence of membrane damage $[58,63,77]$.

3.4. Viruses. The primary target in antiviral PDI depends on the type of virus [38]. Envelope lipids and proteins, capsid and core proteins, DNA, and RNA all are the different components that can be targets of photoprocess [34, 37]. Smetana et al. [78] studied the photoinactivation of herpes simplex virus type 1 (HSV-1) with two cationic phthalocyanines and an anionic dye. They observed major changes in viral proteins, in particular, glycoprotein $\mathrm{D}(\mathrm{gD})$, a structural protein of the HSV envelope. The inactivation of envelope protein impairs their ability to enter into host cell thereby reducing viral infection. Nonenveloped T7 phage effectively undergoes photoinactivation in presence of cationic porphyrins TriP4 and TMPyP [37]. The porphyrins efficiently bind to DNA even in the dark but total virus inactivation occurs after illumination. At appropriate doses of porphyrins, the structural integrity of DNA and viral proteins is affected leading to reduction in the viability of $\mathrm{T} 7$ bacteriophage. The effect of $\mathrm{MB}$ on reverse transcriptase (RT), HIV-1 associated protein p24, and viral RNA in HIV-1 was studied by Bachmann et al. [34]. RT was completely inhibited after the whole virus inactivation by $\mathrm{MB} /$ light treatment. Also, Western blotting and polymerase chain reaction (PCR) inhibition assay showed alteration in HIV-1 p24 and the destruction of its RNA. All the results discussed above lead to the conclusion that phototreatment of viruses in presence of photosensitizers are effective in their destruction and this could be promising alternative in treating viral infections.

\section{Factors Effecting Phototreatment of Water}

4.1. Type of Photosensitizer/Photocatalyst. Several photosensitizers/photocatalysts are available that can be employed in photodisinfection. In order to display superior photodynamic action, the photosensitizer/photocatalyst must fulfill certain criteria. Some properties which must be possessed by an ideal photosensitizer are listed as follows:

(1) high absorption coefficient in the spectral region of the excitation light especially blue light as it is the most penetrating in waters,

(2) long lived triplet excited state and high quantum yield for the generation of ROS (in particular singlet oxygen),

(3) photo stability,

(4) broad spectrum of action in order to efficiently act on infections involving a heterogeneous flora of pathogens,

(5) the photoinactivation mechanism with minimal risk of inducing selection of resistant strains or promoting the onset of mutagenic processes,

(6) low or no toxicity in the dark.

Organic photosensitizers such as $\mathbf{M B}, \mathbf{R B}$, and porphyrin related molecules as well as transition metal complexes (in particular bipyridine and phenanthroline complexes of $\mathrm{Ru}(\mathrm{II}))$ have been the focus of research and development in the last few years $[8,22,24,50,60,79]$. In order to have an antimicrobial activity in the broad spectrum, the photosensitizers must effectively kill bacteria (both Gram-positive and Gram-negative bacteria), fungi, and viruses. Gram-negative bacteria are more resistant than the Gram-positive bacteria owing to the presence of complex lipopolysaccharide layer in addition to the thick peptidoglycan cell membrane which limits the permeability of the photosensitizer into the cell. Hence, either disinfection of Gram-negative bacteria with organic sensitizers requires the presence of membrane disrupting agents (cationic polypeptide polymyxin B or EDTA) or that the photosensitizer bears a positive charge so that they bind to the negatively charged surface and displace cations, thereby changing the arrangement of lipopolysaccharide resulting in alteration of the barrier properties of cell wall [80]. Many authors have successfully reported the inactivation of Gram-negative bacteria like E. coli using positively charged photosensitizers. Merchat et al. [57] while 
using 4 different meso-substituted porphyrins ( 2 cationic and 2 anionic) found that the all porphyrins were effective against Gram-positive bacteria whereas Gram-negative bacteria were almost insensitive to anionic porphyrins. However, Jemli et al. [81] have reported the better activity of $\mathrm{RB}$ (di anionic) than MB (mono cationic) against fecal coliforms referring the enhanced activity of the former to better photophysical properties (high quantum yield of singlet oxygen and better absorption). Nonetheless, more recent studies proving that cationic dyes are more effective in destroying Gram-negative bacteria are published $[50,52,84]$. Caminos et al. [82] have studied the effect of an anionic and four cationic porphyrins with different pattern of meso-substitution by 4 (3-N, N, N-trimethylammoniumpropoxy) phenyl (A) and 4(trifluoromethyl) phenyl (B) groups. They have found that cationic porphyrins are rapidly bound to $E$. coli cells with the highest binding for $\mathrm{A}_{3} \mathrm{~B}^{3+}$ porphyrin (tricationic) and the photosensitized inactivation followed the order $\mathrm{A}_{3} \mathrm{~B}^{3+}>$ $\mathrm{A}_{4}{ }^{4+} \gg \mathrm{ABAB}^{2+}>\mathrm{AB}_{3}{ }^{+}$. Under the same conditions, anionic sensitizer $\left(\mathrm{TPPS}_{4}{ }^{4-}\right.$ ) had negligible effect on $E$. coli. Similar results were obtained by Jiménez-Hernández et al. [83] supporting the condition of presence of positive charge on photosensitizer to inactivate Gram-negative bacteria. Providing more evidence in this area, Lopes et al. [77] show that the number of charges on photosensitizer and their distribution had clear effect on lipid oxidation and photoinactivation efficiency in E. coli. The order of total inactivation efficiency after 270 min of irradiation was Tetra- $\mathrm{Py}^{+}-\mathrm{Me}$ and $\mathrm{Di}-\mathrm{Py}^{+}-$ $\mathrm{Me}-\mathrm{PF}_{\mathrm{adj}}$ with higher efficiencies followed by Tri-Py ${ }^{+}-\mathrm{Me}-$ $\mathrm{PF}$ and $\mathrm{Di}-\mathrm{Py}^{+}-\mathrm{Me}-\mathrm{PF}_{\mathrm{opp}}$. Formation of lipid hydroperoxides and saturated fatty acids (photooxidation products) follows a different order of efficiency. Overall, they conclude that Tetra- $\mathrm{Py}^{+}-\mathrm{Me}, \mathrm{Di}-\mathrm{Py}^{+}-\mathrm{Me}-\mathrm{PF}_{\mathrm{adj}}$, and Tri-Py ${ }^{+}-\mathrm{Me}-\mathrm{PF}$ were more efficient photosensitizers than Mono- $\mathrm{Py}^{+}-\mathrm{Me}-\mathrm{PF}$ and Di- $\mathrm{Py}^{+}-\mathrm{Me}-\mathrm{PF}_{\text {opp }}$.

Both photosensitizers and photocatalysts bring about the photodisinfection of polluted waters. $\mathrm{TiO}_{2}$ among the inorganic catalysts $\left(\mathrm{TiO}_{2}, \mathrm{ZnO}, \mathrm{Fe}_{2} \mathrm{O}_{3}, \mathrm{WO}_{3}\right.$, and $\left.\mathrm{CdSe}\right)$ is a model catalyst that is generally used for these types of processes. $\mathrm{TiO}_{2}$ is inexpensive, nontoxic, and insoluble which makes it attractive to be used in photocatalytic process. $\mathrm{TiO}_{2}$ effectively kills Gram-positive and Gram-negative bacteria as well as viruses as summarized by Mills and Le Hunte [13]. Many have reported the successful inactivation of Gramnegative bacterial strains with $\mathrm{TiO}_{2}$, although with differing photosensitivities [1] unlike organic sensitizers which require positive charged moieties on the molecule in order to break the lipopolysaccharide membrane in Gram-negative bacteria. Comparing the efficiencies of organic photosensitizers and $\mathrm{TiO}_{2}$, Rengifo-Herrera et al. [84] have shown that better inactivation was achieved by the sensitizing dyes compared to $\mathrm{TiO}_{2}$. They have attributed this enhanced activity to better attack on the bacterial membrane, higher quantum yield of ROS, greater absorption of the incident photonic flux by the dyes than $\mathrm{TiO}_{2}$, and improved photostability of the dyes. Also, the results obtained by Benabbou et al. [19] are in concurrence with the above discussion. They have observed that the aromatic photosensitizers on silica performed better than $\mathrm{TiO}_{2}$ even when the molar concentrations of the active photosensitizers on silica were much lower than that of $\mathrm{TiO}_{2}$. The bacterial inactivation rate constants of the aromatic photosensitizers were much higher than $\mathrm{TiO}_{2}$. But, it must also be considered that $\mathrm{TiO}_{2}$ acts immediately whereas the aromatic photosenistizers show photosensitized activity only after an induction time (latency period) of $60 \mathrm{~min}$ under illumination.

Different semiconductors show different photoefficiencies owing to their bandwidth between the valence band and the conduction band. Different samples of $\mathrm{TiO}_{2}$ itself (rutile and anatase) exhibit different efficiencies. Rutile $\mathrm{TiO}_{2}$ (bandwidth $=3.0 \mathrm{eV}$ ) is activated by visible light itself but is less efficient than anatase $\mathrm{TiO}_{2}$ (bandwidth $=3.2 \mathrm{eV}$ ). Mills and Le Hunte [13] have attributed these differences in activities of semiconductors to different morphology, crystal phase, specific surface area, particle size, and surface density of $\mathrm{OH}$ groups in the $\mathrm{TiO}_{2}$ samples. Photocatalytic activity of semiconductors other than $\mathrm{TiO}_{2}$ has also been studied and demonstrated recently. $\mathrm{ZnO}$ is another semiconductor which is gaining attention due to its outstanding performance in photocatalytic process $[76,85-88] . \gamma$-irradiated $\mathrm{ZnO}$ nanorods on glass substrate showed degradation of $E$. coli under sunlight irradiation [87]. $\mathrm{ZnO}$ nanorod films induced a positive effect on bacteria photocatalytic inactivation as compared to only photolysis (without $\mathrm{ZnO}$ ). The disinfection efficiencies were found to depend on the pretreatment of $\mathrm{ZnO}$ precursor with $\gamma$-irradiation. Only the seed precursors (zinc acetate) irradiated with 20 and $30 \mathrm{kGy}$ showed photodisinfection. $\mathrm{ZnO}$ samples of different morphologies have shown to exhibit different antibacterial efficiencies. Talebian et al. [88] have found that flower-like $\mathrm{ZnO}$ showed significantly higher photocatalytic inactivation than $\mathrm{ZnO}$ rod and sphere-like $\mathrm{ZnO}$ against E. coli. Liu and Yang [86] compared the photocatalytic inactivation of $E$. coli and $L$. helveticus by both $\mathrm{ZnO}$ and $\mathrm{TiO}_{2}$. They found that with $2 \mathrm{gL}^{-1} \mathrm{ZnO}$ in $40 \mathrm{~min}$ of irradiation with $365 \mathrm{~nm}$ UV light, the disinfection rate constants were $4.5 \times 10^{-1}$ and $2.2 \times$ $10^{-1} \mathrm{~min}^{-1}$ for $E$. coli and L. helveticus, respectively. With similar conditions, the rate constants for $\mathrm{UV}-\mathrm{TiO}_{2}$ systems were $3.7 \times 10^{-1} \mathrm{~min}^{-1}$ and $1.8 \times 10^{-1} \mathrm{~min}^{-1}$ for $E$. coli and L. helveticus, respectively. They have observed that use of air as a purging gas provides higher bactericidal activity as compared to nitrogen. In this case, $\mathrm{ZnO}$ proved to be more effective than $\mathrm{TiO}_{2}$ under similar experimental conditions. Similar results were obtained by Seven et al. [14] who have tested photocatalytic efficiencies of $\mathrm{TiO}_{2}$ and $\mathrm{ZnO}$ on a series of bacteria and fungi. In another study [76], $\mathrm{ZnO}-\mathrm{TiO}_{2}$ nanocomposite was prepared for photocatalytic disinfection of $E$. coli and detoxification of cyanide. The nanocomposite absorbs visible light (unlike $\mathrm{TiO}_{2}$ which absorbs UV radiation) and also has better efficiency for $E$. coli disinfection and cyanide detoxification than $\mathrm{TiO}_{2} \mathrm{P} 25$. Nano- $\mathrm{WO}_{3}$ has also been investigated for its photocatalytic activity against E. coli [89]. The disinfection efficiency was compared to that of micro- $\mathrm{WO}_{3}$ which revealed that nano- $\mathrm{WO}_{3}$ showed higher bacteria rate than micro- $\mathrm{WO}_{3}$. In a recent study, a bismuth oxy halide BiOI was employed for disinfection of 
E. coli using visible light [90]. BiOI was used as a composite with silver which provided a disinfection efficiency of $99.99 \%$ and significantly higher than that of BiOI. Likewise, other modified semiconductors like silver- $\mathrm{TiO}_{2}$ [91], silver- $\mathrm{ZnO}$ [92], $\mathrm{Cd}-\mathrm{TiO}_{2}$ [93], and $\mathrm{TiO}_{2}$ graphene [94, 95] are the most recently studied semiconductor systems for photocatalysis and they appear promising for water purification.

Both inorganic and organic photosensitizers lead to cell death but it is important to consider that hydroxyl radicals are photogenerated with semiconductors whereas $\mathrm{MB}, \mathrm{RB}$, porphyrins, phthalocyanines, and metal complexes are ${ }^{1} \mathrm{O}_{2}$ producing sensitizers. According to Manjón et al. [48], singlet oxygen is advantageous over hydroxyl radical as it is more selective, requires lower quantity of sensitizer as compared to supported $\mathrm{TiO}_{2}$, and can be generated using visible light in contrast to $\mathrm{TiO}_{2}$ generated radicals which uses UV radiation. Henceforth in the review, only $\mathrm{TiO}_{2}$ among the semiconductors will be taken as a model for comparison purposes.

4.2. Concentration of Photosensitizer. The photocatalytic inactivation rate depends on the concentration of the photosensitizers used. It is expected that the inactivation rate increases with increase in photosensitizer concentration. This behavior is actually observed by many $[40,42,84,96,97]$. Acher et al. $[40,42]$ have studied the photoactivity of MB and RB in water treatment. They reported that microorganisms were more sensitive to singlet oxygen inactivation than organic pollutants as they succeeded in destroying sewage coliforms $\left(1.3 \times 10^{9}\right.$ coliforms in $\left.100 \mathrm{~mL}\right)$ with mild photooxidation conditions $\left(3.5 \mathrm{~m} \mathrm{gL}^{-1} \mathrm{MB}\right.$ at $68 \mu \mathrm{Em}^{-2} \mathrm{~s}^{-1}$ of sunlight). Complete bacterial inactivation was obtained with $0.5 \mathrm{mgL}^{-1}$ with $28 \mathrm{~min}$ of sunlight irradiation. The same group achieved complete destruction of algae at concentration as less as $0.25 \mathrm{mgL}^{-1}$ of $\mathrm{MB}$ and $0.60 \mathrm{mgL}^{-1}$ of $\mathrm{RB}$. Gerba et al. [65] have shown that poliovirus could be readily photoinactivated by $\mathrm{MB}$ (about $4 \mathrm{mgL}^{-1}=5 \mu \mathrm{M}$ ) and visible light in 5 minutes of illumination. They have observed that above $8-9 \mathrm{mgL}^{-1}$ of $\mathrm{MB}$ concentration had little effect on the efficiency and that considerable inactivation occurs in dark above $20 \mathrm{mgL}^{-1}$ of MB. Similar other studies have shown that small concentrations in the range of 5 to $20 \mu \mathrm{M}$ are sufficient to achieve efficient disinfection [53, 54, 60]. Manjón et al. [48] have studied the photoefficiency of $\mathrm{RDP}^{2+}$ and $\mathrm{RDB}^{2+}$ on porous silicone at a loading of $2 \mathrm{~g} \mathrm{~m}^{-2}$ to inactivate $E$. coli and E. faecalis. The films produced 2-3-log reduction in the microbial population with initial concentration $10^{2}$ and $10^{4} \mathrm{CFU} \mathrm{mL}{ }^{-1}$. This efficiency was unchanged regardless the type of bacteria and their initial concentration.

Rincón and Pulgarin [96] have studied the effect of $\mathrm{TiO}_{2}$ concentration on the photocatalysed inactivation. They have observed that increasing the $\mathrm{TiO}_{2}$ concentration from $0.025 \mathrm{gL}^{-1}$ to $1 \mathrm{gL}^{-1}$ increases the inactivation rate whereas $\mathrm{TiO}_{2}$ concentrations above $1 \mathrm{gL}^{-1}$ do not significantly increase the inactivation rate. Within $45 \mathrm{~min}$ of irradiation, complete destruction was observed with $1 \mathrm{gL}^{-1} \mathrm{TiO}_{2}$. In fact, they propose that the photoactivity of the catalyst is less effective beyond $1 \mathrm{gL}^{-1}$ due to weak light penetration into the bulk of the solution and also the concomitant action of light on bacteria is diminished (only light $<400 \mathrm{~nm}$ can also cause disinfection). Schwegmann et al. [97] have studied the disinfection rates of $E$. coli at different $\mathrm{TiO}_{2}$ concentrations ranging from 0.3 to $1 \mathrm{gL}^{-1}$. They found that the highest disinfection rate was exhibited by the highest concentration of $\mathrm{TiO}_{2}$. No experiments were carried out beyond these concentrations considering the toxicity of the $\mathrm{TiO}_{2}$ in dark at higher concentrations. It can be generalized that increase in photosensitizer concentration increases the photoactivity but only up to a threshold value after which it remains unchanged $[60,65,97]$ or lowers the efficiency $[96,98]$. Although the concentration of photosensitizers has a significant effect on the rate of water disinfection, other parameters such as photosensitizers form (free or fixed), the irradiation time, and the light intensity also greatly influence the effects of photosensitizers concentration on the inactivation process $[60,82,96]$.

4.3. pH Effect. Acher et al. (1990) [99] have found that increasing the $\mathrm{pH}$ of the effluent of wastewater treatment plant from 7.1-7.6 to 8.6-8.9 improved the photodisinfection efficiency with $\mathrm{MB}$ as a sensitizer. Schäfer et al. [63] also have observed, in photosensitization with $\mathrm{RB}$, a significant decrease in E. coli survival at higher $\mathrm{pH}$ than 7.0. They report that, at $\mathrm{pH}$ indices below and above $\mathrm{pH}=7.0$, the survival of bacteria reduces by several logs. But, at $\mathrm{pH}=$ 9.6 without the sensitizer, it showed remarkable increase in photoinactivation (the alkaline $\mathrm{pH}$ is rendering toxicity) whereas no photokilling is observed at $\mathrm{pH}=7.0$ and 4.5 in the absence of sensitizer. On the other hand, Cooper and Goswami [44], on changing the $\mathrm{pH}$ from 7.0 to 10.0, did not observe any significant change in the photodisinfection rates by methylene blue. Another factor which influences the effect of $\mathrm{pH}$ is the pretreatment of Gram-negative bacteria with polycationic agents. Polycations like peptides bind tightly to the negatively charged cell membrane thereby exchanging divalent cations and changing the physical arrangement of lipopolysaccharide [98]. While using such polycations, the sensitizer is bound to the polycation which facilitates the latter's penetration into the cell membrane. Nitzan et al. [80] report that decreasing the $\mathrm{pH}$ from 8.5 to 6.5 increased the binding constant of deuteroporphyrin (DP) to polycationic agent polymyxin nonapeptide (PMNP) that consequently increases the penetration of sensitizer into $E$. coli and $P$. aeruginosa cell membrane.

In semiconductor based photodisinfection, the $\mathrm{pH}$ of water under disinfection affects the charge, particle size, and the position of conductance and valence bands of the semiconductor [1, 6, 100]. Melián et al. [101] have studied the effect of different $\mathrm{pH}$ (5 and 7.8) on the disinfection rate. They observed that the disinfection rate increases at pH 5 as compared to $\mathrm{pH}$ 7.8. Schwegmann et al. [97] have also observed that the change in $\mathrm{pH}$ affects the disinfection rate. Rincón and Pulgarin [100] however did not find any significant effect of the initial $\mathrm{pH}$ on the disinfection rate. The illumination of $\mathrm{TiO}_{2}$ in water leads to decrease in $\mathrm{pH}$ from 
7.0 to 5.5 due to production of hydroxyl radicals and protons. They propose the disinfection process is a cumulative effect of $\mathrm{pH}$ modification, direct action of sunlight, and attack of ROS generated during illumination on $\mathrm{TiO}_{2}$.

4.4. Wavelength and Intensity of Incident Light. Organic dyes, aromatic hydrocarbons, porphyrin and related compounds, phthalocyanine, and transition metal complexes have strong absorbance in the UV-visible region with high quantum yield of singlet oxygen [8]. Dyes like $\mathrm{MB}, \mathrm{RB}$, and eosin are absorbed in the visible region $(\lambda>400 \mathrm{~nm})$. It is important to irradiate the system under study with light of appropriate wavelength so that the photosensitizer can transform itself to the longer lived triplet state and transfer its energy to molecular oxygen to generate ROS. Porphyrins and related compounds however are absorbed at several wavelengths in the UV-visible region with the Soret band in the blue region (360-400 $\mathrm{nm}$ ) enabling us to use the most penetrating blue light in water $[5,8,102]$ and the Q-bands in the red region $(600-800 \mathrm{~nm})$. This makes it possible to use visible light for photodisinfection as these materials can produce ROS in presence of light of wavelength ranging from 360 to $800 \mathrm{~nm}$. Schäfer et al. [63] have indicated the wavelength dependence of disinfection. They found a very small effect of the wavelengths below $435 \mathrm{~nm}$ (UVA) and above in the absence of sensitizer than in the presence of RB. It means that the photocatalytic activity is a combined action of light and the photosensitizer in the presence of oxygen and the contribution of only UV component is negligible. Many researchers have used sunlight or solar simulated light sources for photodisinfection [42, 46, 48, 79, 81, 99, 117]. Also, while using organic sensitizers, the intensity of the light is not a limiting factor for photocatalytic disinfection [42]. Acher et al. $[99,103]$ carried out disinfection experiments in all the four seasons of the year, the sunlight intensity varying from 700 to $2100 \mu \mathrm{E} \mathrm{m}^{-2}$. In spite of the different sunlight intensities, they obtained good microbiological results in all the seasons. The same group [104] carried out photodisinfection under concentrated sunlight using heliostats to reflect sunlight. Concentrated sunlight $\left(17 \times 10^{4} \mathrm{~W} \mathrm{~m}^{-2}\right)$ caused 5log decrease in the microorganisms survival in 3 seconds as compared with normal sunlight $\left(850 \mathrm{~W} \mathrm{~m}^{-2}\right)$. Alouini and Jemli [22] have reported increase in percentage destruction of Ascaris eggs and Taenia with increasing light intensities from 800 to $5000 \mathrm{~W} \mathrm{~m}^{-2}$ in presence of TMPyP. Cooper and Goswami [44] have obtained complete destruction of E. coli in less than $10 \mathrm{~min}$ with $10 \mathrm{~m} \mathrm{gL}^{-1}(31 \mu \mathrm{M}) \mathrm{MB}$ with average sunlight intensity of $715-775 \mathrm{~W} \mathrm{~m}^{-2}$. Magaraggia et al. [46] employed Quartz halogen lamp with UV and IR filters with fluence rate of $1000 \mathrm{~W} \mathrm{~m}^{-2}$ in combination with cationic porphyrins. The photosensitizers caused reduction in survival of $S$. aureus, E. coli, and fungal pathogen Saprolegnia spp. after just 20 min irradiation. Jemli et al. [81] carried out photodisinfection of fecal coliforms using TMPyP, RB, and $\mathrm{MB}$ under sunlight $(400-700 \mathrm{~nm})$ with fluence rate of $9.5 \times 10^{-2} \mathrm{~W} \mathrm{~m}^{-2}$. The best result was achieved by TMPyP at a concentration of $5 \mu \mathrm{M}$ with $180 \mathrm{~min}$ of irradiation. Carvalho et al. [41] have used white light with intensity of
$90 \mathrm{~W} \mathrm{~m}^{-2}$ and successfully photoinactivated fecal coliforms in $240 \mathrm{~min}$, respectively, even at low concentration of $1 \mu \mathrm{M}$ of cationic porphyrins (Tetra- $\mathrm{Py}^{+}-\mathrm{Me}$, TriP4-COOH). On the other hand, Orlandi et al. [62] irradiated cultures with $500 \mathrm{~W}$ halogen tungsten lamp (fluence rate $480 \mathrm{~W} \mathrm{~m}^{-2}$ ) and found that cationic porphyrins caused considerable log reduction in both laboratory model microorganisms as well as waste water microflora in $75 \mathrm{~min}$ irradiation. Twofold increase in the irradiation time (i.e., doubling the light dose) resulted in further decrease of only 1-log unit of the monitored microflora. Rossi et al. [60] have used two different light sources with very low intensities: incandescent light bulb (white light with UV radiation cut off, $40 \mathrm{~W} \mathrm{~m}^{-2}$ ) and multi-LED lamp at different fluence rates $\left(24 \mathrm{~W} \mathrm{~m}^{-2}\right.$ and $40 \mathrm{~W} \mathrm{~m}^{-2}$ ). They observe that irradiation with incandescent light bulb in presence of pentaphyrin PCCox at a fluence of $40 \mathrm{~W} \mathrm{~m}^{-2}$ caused almost 5-log reduction in the $S$. aureus survival within $15 \mathrm{~min}$ of treatment and 6 logs after $60 \mathrm{~min}$ while with multi-LED lamp caused only 2 logs in $15 \mathrm{~min}$ and almost 5 logs in $60 \mathrm{~min}$. This indicates that using a wider spectrum of the light energy (incandescent lamp) is more efficient than a small part of the spectrum (multi-LED lamp). Also, it is seen that almost halving the fluence rate (from 40 to $24 \mathrm{~W} \mathrm{~m}^{-2}$ ) does not have a significant effect on the photodisinfection.

The production of electron hole pair in $\mathrm{TiO}_{2}$ requires illumination by light of energy greater than or equal to the band gap between the valence band and conduction band (as already discussed). This energy can be obtained from light of wavelength $<400 \mathrm{~nm}$. UV region of the electromagnetic spectrum consists of UV-A (315 to $400 \mathrm{~nm}), \mathrm{UV}-\mathrm{B}$ (280 to $315 \mathrm{~nm})$, and UV-C (100 to $280 \mathrm{~nm}$ ) components. The germicidal UV-C component of solar radiation does not reach the earth as it is absorbed by the atmosphere [6], whereas UV-A and UV-B reach the earth's surface $[1,6]$. In solar disinfection of water (SODIS), UV-A radiation is responsible for the disinfection effect due to the production of reactive oxygen species in presence of oxygen. However, during solar irradiation, the presence of $\mathrm{TiO}_{2}$ enhances the disinfection process due to the massive generation of ${ }^{\bullet} \mathrm{OH}$ radicals and the perturbation of the cell processes and death $[96,105]$. The dependence of disinfection on light intensity has been studied by many $[96,105,106]$. Rincón and Pulgarin [96] have seen that the light intensity did not significantly affect the bacterial disinfection. They found that increasing the light intensity from 400 to $1000 \mathrm{~W} \mathrm{~m}^{-2}$ in presence of $\mathrm{TiO}_{2}$ increased the initial inactivation rate from $7.4 \times 10^{6}$ to only $9.9 \times 10^{6}$, respectively. They have reported that effect of intensity is more on the system without $\mathrm{TiO}_{2}$. The same group has studied the effect of intensity under direct sunlight [105]. Complete inactivation of E. coli was obtained in both summer and winter periods. However, they propose that UV solar dose is not an appropriate parameter to predict the photocatalytical impact on bacteria as E. coli survival acts differently during both irradiation and postirradiation periods. Similar conclusions were drawn by Sichel et al. [106] in an effort to study the effect of solar light intensity on the photocatalytic disinfection of bacteria and fungi. According 
to them, a minimum solar dose is enough to bring about photocatalytic activity; any further increase does not enhance the disinfection efficiency.

4.5. Water Quality. The presence of contaminants (organic or inorganic), turbidity, and the $\mathrm{pH}$ of water all affects the rate of photocatalytic disinfection. The fact that the photodisinfection efficiency is greatly influenced due to suspended solids, dissolved oxygen (DO) and $\mathrm{pH}$ have been reported by many $[17,22,40,81,99,104]$. In their pilot plant studies, Acher et al. [99] found that the photodisinfection efficiency fell sharply when the turbidity exceeded 25 NTU. Back in 1977, Acher and Rosenthal [40] had observed reduction in photodisinfection efficiency as the colloids in the effluent tend to adsorb the photosensitizer, protect the microorganism, and reduce the light penetration into the waters. However, they succeeded in reducing the turbidity by flocculating the effluent with bentonite clay while aiming for the dye removal by the clay. Acher et al. [104] suggest that the turbidity of the entering effluent should be $<20$ NTU for efficient photodisinfection process. Photodisinfection process proceeds in presence of the dissolved oxygen in the water to be treated. The minimum DO required for an efficient disinfection process is approximately $2.0 \mathrm{mg} \mathrm{O}_{2} \mathrm{~L}^{-1}$ as per the studies of Acher et al. [103]. They have also carried out photodisinfection with MB [104] with varied amount of DO ( 8 and $35 \mathrm{mg} \mathrm{O}_{2} \mathrm{~L}^{-1}$ ) and found that increasing the DO from 8 to $35 \mathrm{mg} \mathrm{O}_{2} \mathrm{~L}^{-1}$ did not affect the results.

Rincón and Pulgarin [96] have observed that water turbidity negatively affects the photodisinfection. Turbidity affects the penetration of light through water thus limiting the total absorption of efficient photons. Turbidity in water results due to presence of insoluble particulates as well as by increase in the suspended $\mathrm{TiO}_{2}$ concentration. Chong et al. [6] have mentioned in their review that 5 nephelometric turbidity units (NTU) are the limit of turbidity in order to effectively utilize UV light. The effect of presence of heavy metals in water during photodisinfection is also mentioned [6]. The presence of these in trace amounts is toxic and can be carcinogenic also. However, the photocatalytic process simultaneously converts them into their nontoxic ionic states and can be removed as crystallites deposited on the photocatalyst. Further, Rincón and Pulgarin [100] have reported the effect of various parameters on $E$. coli photocatalytic disinfection. They have found that the addition of some inorganic ions like $\mathrm{HCO}_{3}{ }^{-}, \mathrm{HPO}_{4}{ }^{2-}, \mathrm{Cl}^{-}, \mathrm{NO}_{3}^{-}$and $\mathrm{SO}_{4}{ }^{2-}$, affects the sensitivity of bacteria to photodisinfection by $\mathrm{TiO}_{2} \cdot \mathrm{HCO}_{3}{ }^{-}$ and $\mathrm{HPO}_{4}{ }^{2-}$ cause a decrease in the photoactivity while $\mathrm{Cl}^{-}, \mathrm{NO}_{3}^{-}$, and $\mathrm{SO}_{4}{ }^{2-}$ have a weak influence on the photokilling effect of $\mathrm{TiO}_{2}$. But, they have observed that these ions have no effect on the photodegradation of resorcinol, indicating that photodisinfection is a more sensitive process than photodegradation of contaminants. Hence, in order to carry out effective photodisinfection, it is advisable to reduce the suspended particles prior to photocatalytic disinfection. Immobilization of $\mathrm{TiO}_{2}$ can also help in reducing the turbidity caused by the catalyst concentration.
4.6. Free and Fixed Photosensitizer Systems. While using photodynamic systems for water treatment, it is worthwhile to use photosensitizers on a solid support (heterogeneous phase). Employing the photosensitizer as a suspension or a homogenous solution poses a problem of removing the photosensitizers from the water. In their preliminary experiments in 1977, Acher and Rosenthal [40] made an effort to adsorb the dyes on solid ion exchange resin and natural clays but were unsuccessful in efficient photodisinfection as the dye-binding resins reacted with ions in the sewage and released colored compounds. They however chose to carry out photodisinfection using dissolved MB in water followed by removal of dye using bentonite. Similarly, Parakh et al. [54] are of the opinion that the removal of photosensitizers postillumination proves to be efficient in dye separation as well as adsorbing other suspended pollutants. They have employed two water soluble $\mathrm{Ru}(\mathrm{II})$ pyridyl complexes (complex 1 and complex 2) as promising candidate for light inactivation of bacteria and used activated carbon and silica as adsorbents to remove the photosensitizers from water. These efforts are worth mentioning, although scientists are looking forward to adopt heterogeneous systems. Organic photosensitizers, owing to their wide range of functional groups available on them and their solubility in water or solvents, are much feasible for immobilization on solid supports. The anchoring of photosensitizers onto solid supports can be carried out by adsorption [107], polymerization [49], electrostatic interaction [83] conjugation [108], and click reaction [109]. Many researchers have carried out the immobilization of photosensitizers on supports such as magnetic nanoparticles [52, 59], glass [49], resins [43], polymer [47], and silicones [61]. Savino and Angeli [43] immobilized MB, RB, and eosin covalently on polystyrene beads and also coated $\mathrm{MB}$ on granular activated carbon, silica gel, and XAD-2 polystyrene resin. The adsorption of $\mathrm{MB}$ was carried out by suspending the supports in hot agitated water to which a solution of $\mathrm{MB}$ in water was added till it reached saturation. They found that $\mathrm{MB}$ covalently bonded to polystyrene beads was the best photosensitizer with $97.55 \%$ inactivation of $E$. coli in $30 \mathrm{~min}$ of exposure to electrofluorescent cold white light. Activated carbon was found to be the best support for the adsorption of the dye. Jiménez-Hernández et al. [83] synthesized two cationic $\mathrm{Ru}(\mathrm{II})$ phenanthroline complexes $\mathrm{RDP}^{2+}$ and $\mathrm{RBN}^{2+}$ and one anionic $\mathrm{RSD}^{4-} \cdot \mathrm{RDP}^{2+}$ and $\mathrm{RBN}^{2+}$ were immobilized on porous silicone cylinders via adsorption in boiling solutions. $\mathrm{RSD}^{4-}$ was immobilized via electrostatic interaction on cationic nylon, cellulose, and polyvinylidene difluoride. The sensitizer loading was in the order of 1$30 \mathrm{mg} \mathrm{g}^{-1}$ of the polymer in all the cases. The excited state lifetimes of $\mathrm{RBN}^{2+}$ were measured to be $0.3 \mu$ s and that for $\mathrm{RSD}^{4-}$ and $\mathrm{RDP}^{2+}$ were in the range of 2.4 to $4.2 \mu \mathrm{s}$. $\mathrm{RDP}^{2+}$ on silicone had the highest $\mathrm{O}_{2}$ quenching efficiency and singlet oxygen lifetime yielding 5-log decrease in E. coli and E. faecalis count in one hour under a solar simulator lamp. RSD ${ }^{4-}$ / cationic polymer systems produced no disinfection at all. Moreover, photosensitizer leaching was observed in Nylon and cellulose polymers. Yet in another attempt to achieve higher sensitizer loading and increase efficiency of $\mathrm{RSD}^{4-}$, 
they incorporated it into cationic silicone [79]. Though the surface charge neutralization provides a promising strategy to enhance its photodisinfection properties, the efficient loading onto the polymer still remains a drawback for $\mathrm{RSD}^{4-} / \mathrm{p}$-Sil. On the other hand, $\mathrm{RDP}^{2+}$ has a high loading on the anionic polymer, longer singlet oxygen lifetimes, and better bacterial inactivation rates. The same research group in Spain has evaluated the disinfection efficiency using sunlight, $0.8 \mathrm{~m}^{2}$ compound parabolic collectors, and $\mathrm{RDP}^{2+}$ on siloxane films $\left(2 \mathrm{mg} \mathrm{m}^{-2}\right)$ [17]. They employed two CPC prototypes with different configuration of photosensitizers, namely, coaxial and fin type. With both the photoreactor designs and regardless the bacteria used, the average bacterial inactivation rate was calculated to be $2 \times 10^{4}$ and $2 \times 10^{6} \mathrm{CFU} \mathrm{L}^{-1} \mathrm{~h}^{-1}$. They have also studied the effect of various factors influencing the performance of solar reactors using immobilized sensitizers on silicone [48] and the effect of dye reloading to water disinfection with solar reactors [61]. The reloading of the dye on the polymer is readily achieved and performs better than the original ones. They have successfully demonstrated that immobilized dyes can be a potential tool for drinking water disinfection using solar reactors. Loading of the dye on different polymers has been studied by other researchers as well $[47,53,110,111]$. Bonnett et al. [47] have used chitosan membrane to support 2 different porphyrins ( $p$-THPP and $p$-TAPP) and a $\mathrm{Zn}(\mathrm{II})$ phthalocyanine (ZnPcS), by adsorption, dissolution, and casting and by covalent attachment. Photomicrobicidal studies on $E$. coli were conducted using static photoreactor and circulating water photoreactor systems. ZnPcS/chitosan membrane with a loading of $9 \mu \mathrm{g} \mathrm{cm}^{-2}$ gave the best performance with complete disinfection in $90 \mathrm{~min}$ of illumination. These membranes were still $50 \%$ effective even after 9 months of storage in the dark. The drawback of brittle chitosan membrane was also overcome with reinforced membranes which were prepared by casting the polymer on nylon net support. Nakonechny et al. [110] studied the disinfection efficiencies of RB and MB immobilized on polystyrene membranes. $99 \%$ enclosure of the photosensitizer in the polymer was ensured and the films exhibited high antimicrobial properties against $S$. aureus and E. coli. An interesting alternative to prepare immobilized photosensitizers on optically transparent indium tin oxide (ITO) is reported by Funes et al. [49]. The films were formed by electrochemical polymerization of a metal free porphyrin TDAP and Pd-porphyrin (Pd-TDAP) complex on ITO, the two electrochemical active centers being the porphyrin core and the triphenylamine (TPA) moieties. Also, the TPA groups undergo radical cation dimerization to produce tetra phenyl benzidine (TPB). Experiments with these films in solution showed photooxidation of dimethyl anthracene and L-Tryptophan was observed indicating the presence of photodynamic action of the polymeric films. In vitro experiments with $E$. coli and Candida albicans caused a decrease of $\approx 3 \operatorname{logs}$ and $\approx 2.5 \operatorname{logs}$, respectively. Phthalocyanines of zinc and aluminum were covalently immobilized to nano-aminopropyl silica gel by Kuznetsova et al. [53]. In this paper, they have reported that the photodisinfection efficiencies of photosensitizers immobilized on nanoparticles are comparable to those in homogenous solutions due the enormous surface of nanocarriers. However, in such systems the separation of photosensitizers and increase in turbidity due to silica gel remain the drawbacks. Such limitations can be overcome by using magnetic nanoparticles as supports for the photosensitizers. Photosensitizers on nanomagnets are successfully prepared and their use and reuse in photodisinfection are described [52, 112, 113]. Carvalho et al. [52] have synthesized cationic nanomagnet-porphyrin hybrids and studied their photodisinfection capabilities against $E$. coli, E. faecalis, and T4-like phage. They have reported good stability of these hybrids in water and effective antimicrobial activity. The hybrid materials possess good photostability as well and hence can be efficiently recovered and reused for photodisinfection. Recycling and reuse capability of such nanomagnet-porphyrin hybrids was also studied by Alves et al. [59]. Two nanomagnet-porphyrin hybrids differing in core particle $\left(\mathrm{Fe}_{3} \mathrm{O}_{4}\right.$ and $\left.\mathrm{CoFe}_{2} \mathrm{O}_{4}\right)$ were subjected to recycling and reuse along with reuse assays of a nonsupported cationic porphyrin Tri-Py ${ }^{+}-\mathrm{Me}-\mathrm{PF}$. Results showed that the hybrids maintained high bactericidal efficiencies as comparable to the nonsupported porphyrin even after several photoinactivation cycles. The photostability and the efficiencies retained by these nanomagnet- porphyrin hybrids broaden new horizons of photoinactivation, in particular for water treatment.

Separation of $\mathrm{TiO}_{2}$ catalyst after water treatment is an important issue, although in suspension the availability of catalyst surface to interact with the pollutants is more as compared to fixed $\mathrm{TiO}_{2}$ on a solid support. Conventional methods of separation include $\mathrm{pH}$ adjustments, coagulation, and sedimentation that are time consuming and expensive $[1$, 114]. Immobilization of $\mathrm{TiO}_{2}$ appears to be a suitable alternative to circumvent the catalyst-recovering step posttreatment. However, the limitations that fixed catalyst systems face over the slurry systems are limited mass transport and restricted light penetration thus diminishing the efficiency of the process $[1,91,96]$. Considering the bacteria inactivated per mg of suspended or fixed $\mathrm{TiO}_{2}$, Rincón and Pulgarin [96] have evaluated that fixed $\mathrm{TiO}_{2}$ was more efficient in bacterial inactivation than suspended $\mathrm{TiO}_{2}$. They immobilized $\mathrm{TiO}_{2}$ on Nafion membranes and Pyrex glass surfaces. They found that fixation of $\mathrm{TiO}_{2}$ above $25 \mathrm{mg}$ results in diminishing light penetration and reducing the process efficiency. Van Grieken et al. [91] have immobilized $\mathrm{TiO}_{2}$ (Degussa P25) on glass tubes/rings by dip coating procedure. They have also prepared $\mathrm{Ag} / \mathrm{TiO} \mathrm{O}_{2}$ coated glass surfaces incorporating silver by photocatalytic reduction of silver nitrate simultaneously using titania in suspension or immobilized as wall or fixedbed in the reactor. They have found that $\mathrm{Ag} / \mathrm{TiO}_{2}$ catalytic wall reactor with $0.6 \mathrm{wt} \% \mathrm{Ag}$ loading showed a high activity per gram of $\mathrm{TiO}_{2}$ and good stability of the film. Rubio et al. [115] prepared titania by sol gel method and fixed on borosilicate glass tubes $(70 \mathrm{~mm}$ in length, outer diameter of $42 \mathrm{~mm}$, and glass thickness of $2.3 \mathrm{~mm}$ ). The system was studied to improve the disinfection process of seawater. Two marine bacteria Alteromonas sp. and Corynebacterium stationis were used for the photo experiments. They found that the $\mathrm{TiO}_{2}$ films with UV light were more effective than disinfection with 
UV light itself. Nevertheless, the immobilization of $\mathrm{TiO}_{2}$ on solid support faces limitations and requires much research and trials to be successfully incorporated in large-scale water treatment plants.

\section{Environmental Applications of Photosensitization}

5.1. Disinfection of Water (Bacteria, Virus, and Fungi). Photosensitization efficiently produces ROS which causes toxic effects in bacteria leading to their irreversible death by oxidation of cell wall proteins and membrane disruption [116]. It is nearly a century since the discovery of singlet oxygen and its use for disinfection has been studied widely. However, its application for water disinfection gained attention only in the 1970s [40, 42, 65, 117]. Acher et al. have performed in their various experiments and plant studies the disinfection of coliforms, enterococci [103], algae [117], and poliovirus [99] from sewage water and secondary effluent from wastewater treatment plants and industrial wastewater. More recently, numerous studies have shown that photodynamic inactivation of water is a successful tool for obtaining microbe-free water. Table 2 lists the different microorganisms that can be photoinactivated by organic sensitizers. The concentration giving the best efficiency is indicated in the table although various different concentrations may have been studied in the corresponding cited references. The photodisinfection efficiencies of these materials and the type of irradiation used are also displayed.

Photodynamic destructions of different kinds of bacteria using $\mathrm{TiO}_{2}$ as a catalyst are reported by many $[14,84,96,106]$. Mostly E. coli is considered under study as it is used as biological indicator of disinfection efficiency in water systems [100]. Sichel et al. [106] studied the effect of UV solar intensity on the disinfection efficiency of $\mathrm{TiO}_{2}$ supported on paper and in slurry. The microorganisms used were E. coli and two wild strains of the Fusarium genus, F. solani, and F. anthophilum. They have achieved complete disinfection in different seasons with varied intensity of sunlight. Seven et al. [14] successfully destroyed different bacteria and fungi, namely, Escherichia coli, Pseudomonas aeruginosa, Staphylococcus aureus, Saccharomyces cerevisiae, Candida albicans, and Aspergillus niger using $\mathrm{TiO}_{2}, \mathrm{ZnO}$, and Sahara desert dust as photocatalyst in short period of illumination. Except for $A$. niger, all the bacteria and fungi were susceptible to photocatalytic destruction.

5.2. Decontamination of Water. The solar detoxification of a stable pesticide, bromacil with $\mathrm{MB}$, was studied by Acher et al. [104]. Bromacil was readily decomposed when the ratio of bromacil: $\mathrm{O}_{2}$ was $>1$. Gryglik et al. [67] applied photosensitized oxidation to the degradation of 2-chlorophenol (it causes considerable damage to aquatic bodies and human health). The oxidation was carried out using RB in solution and immobilized on silica gel and satisfactory results were obtained so as to use this method for further investigations in purification of water. Phenol and its chlorinated derivatives were degraded using different phthalocyanines (AlPHC,
ZnPHC, SiPHC, and metal-free PHC) $[11,18]$ in presence of light. Among the photosensitizers used, AlPHC was the most active and metal-free PHC was virtually inactive. Also, sulphonation of the benzene rings of these phthalocyanines render the photosensitizers water soluble [18]. Three zinc phthalocyanines immobilized on mesoporous aluminosilicate have been successfully employed in the degradation of pesticides fenamiphos and pentachlorophenol by Silva et al. [70]. They report $98 \%$ conversion of fenamiphos after $300 \mathrm{~min}$ of irradiation into fenamiphossulfoxide and fenamiphos-sulfone. The main photodegradation product of pentachlorophenol after $300 \mathrm{~min}$ of irradiation was 2,3,5,6-tetrachloro-hydroquinone. Recently, $\mathrm{TiO}_{2}$ catalysts photosensitized with porphyrins are investigated for phototreatment of water [68, 71, 72]. Wang et al. [71] report the photodegradation of 4-nitrophenol using functionalized porphyrin- $\mathrm{TiO}_{2}$ catalyst. They synthesized two kinds of meso-substituted porphyrins, $\mathrm{H}_{2} \mathrm{Pp}(\mathrm{a})$ and $\mathrm{H}_{2} \mathrm{Pp}(\mathrm{b})$, and their corresponding copper(II) complexes $\mathrm{CuH}_{2} \mathrm{Pp}(\mathrm{a})$, $\mathrm{CuH}_{2} \mathrm{Pp}(\mathrm{b})$. $\mathrm{TiO}_{2}$ based photocatalysts were prepared by dissolving these photosensitizers at different concentrations in $\mathrm{CHCl}_{3}$ and adding to these $1 \mathrm{~g}$ of ground $\mathrm{TiO}_{2}$, stirred for $8 \mathrm{~h}$, and solvent was removed under vacuum. The most efficient photodegradation was obtained for an optimal amount of porphyrin equal to $18 \mu \mathrm{mol}$ per $1 \mathrm{~g}$ of $\mathrm{TiO}_{2}$. The photoefficiencies of the porphyrins impregnated with an optimal amount of $18 \mu \mathrm{mol}$ per $1 \mathrm{~g}$ of $\mathrm{TiO}_{2}$ decreased in the order $\mathrm{TiO}_{2}-\mathrm{CuH}_{2} \mathrm{Pp}(\mathrm{b})>\mathrm{TiO}_{2}-\mathrm{CuH}_{2} \mathrm{Pp}(\mathrm{a})>\mathrm{TiO}_{2}-\mathrm{H} 2 \mathrm{Pp}(\mathrm{b})>$ $\mathrm{TiO}_{2}-\mathrm{H}_{2} \mathrm{Pp}(\mathrm{a})$. Nakonechny et al. [110] have investigated the photodegradation of acid chrome blue $\mathrm{K}$ (ACBK) using $\mathrm{TiO}_{2}$ sensitized porphyrins $\mathrm{H}_{2} \mathrm{TPPC}$ or $\mathrm{TNO}_{2} \mathrm{PP}$. Their results indicated that there was remarkable effect of $\mathrm{H}_{2}$ TPPC- $\mathrm{TiO}_{2}$ on degradation of ACBK. Up to $94 \%$ of decolorization was observed in $15 \mathrm{~min}$ under incandescent lamp with initial ACBK concentration of $10 \mathrm{mgL}^{-1}$. Murphy et al. [72] have also prepared a composite photocatalyst to photodegrade the pharmaceutical Famotidine. They absorbed $\mathrm{H}_{2}$ TPPC on $\mathrm{TiO}_{2}$ by two methods. In method $\mathrm{A} \mathrm{H}_{2}$ TPPC was absorbed onto $\mathrm{TiO}_{2}$ in methanol at room temperature and in method B $\mathrm{H}_{2}$ TPPC was absorbed on $\mathrm{TiO}_{2}$ in dimethylformamide (DMF) at reflux. Photodegradation experiments were carried out both under visible light and solar light irradiation. Famotidine was found to degrade into series of intermediate products with S-oxide of Famotidine as the major product but complete mineralization of the drug was not achieved. Also, they have observed that under halogen lamp, TCPP-TiO $2 \mathrm{~A}$ was more efficient than TCPP- $\mathrm{TiO}_{2} \mathrm{~B}$. TCPP alone showed minimal photodegradation and also $\mathrm{TiO}_{2}$ alone displayed poor degradation. Hence, the result was due to the combined action of composite photocatalyst and not the individual components.

Among the various semiconductors used for photocatalysis $\left(\mathrm{TiO}_{2}, \mathrm{ZnO}, \mathrm{Fe}_{2} \mathrm{O}_{3}, \mathrm{CdS}\right.$, and $\left.\mathrm{ZnS}\right), \mathrm{TiO}_{2}$ is the most widely used for oxidation of pollutants in water [1, 114]. The ROS produced in presence of light attack the oxidizable contaminants converting them into $\mathrm{CO}_{2}, \mathrm{H}_{2} \mathrm{O}$, and other diluted inorganic acids. The main pollutants in water encountered are chlorinated solvents, nonchlorinated solvents, insecticides, pesticides, dyes, and detergents and 


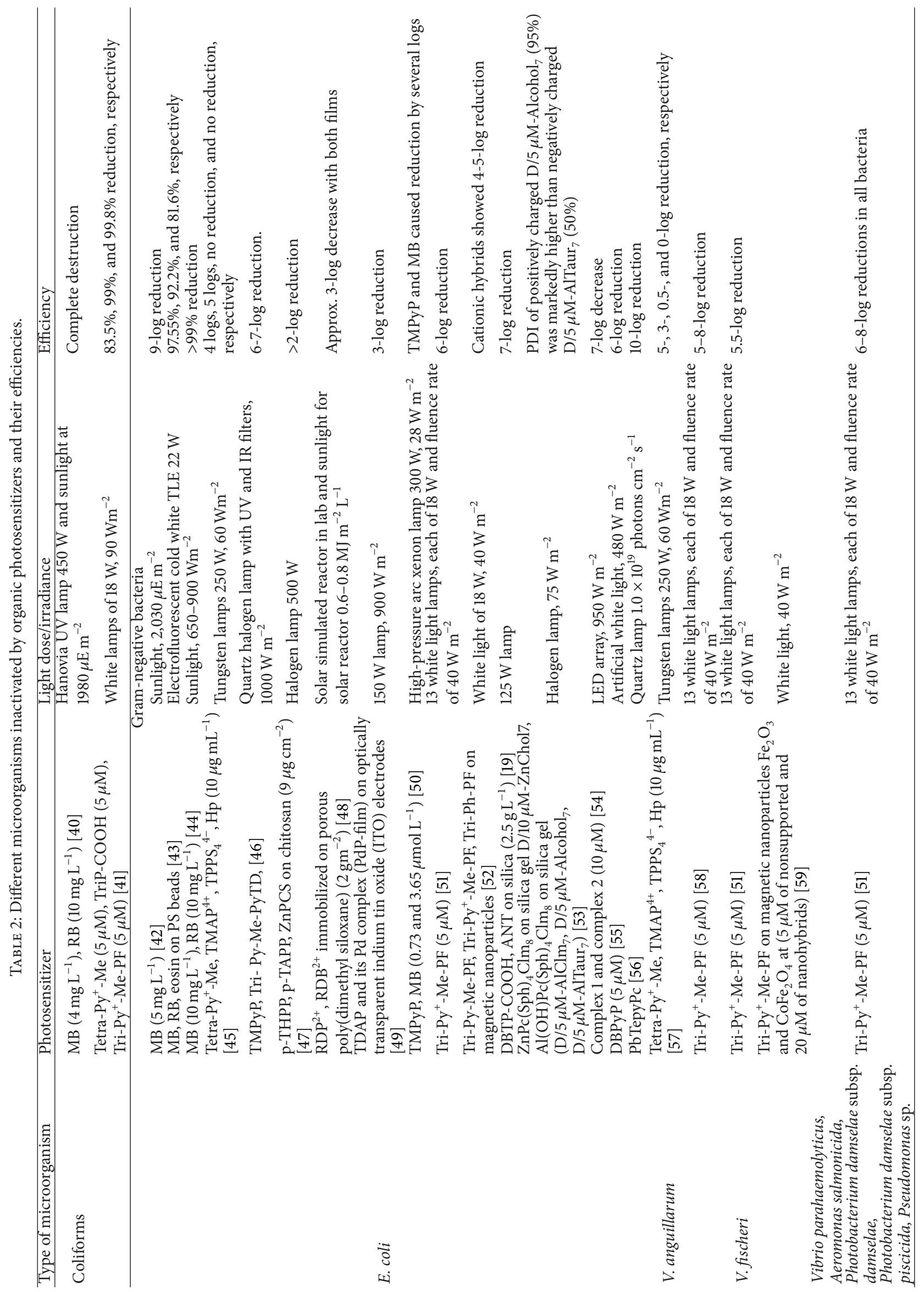




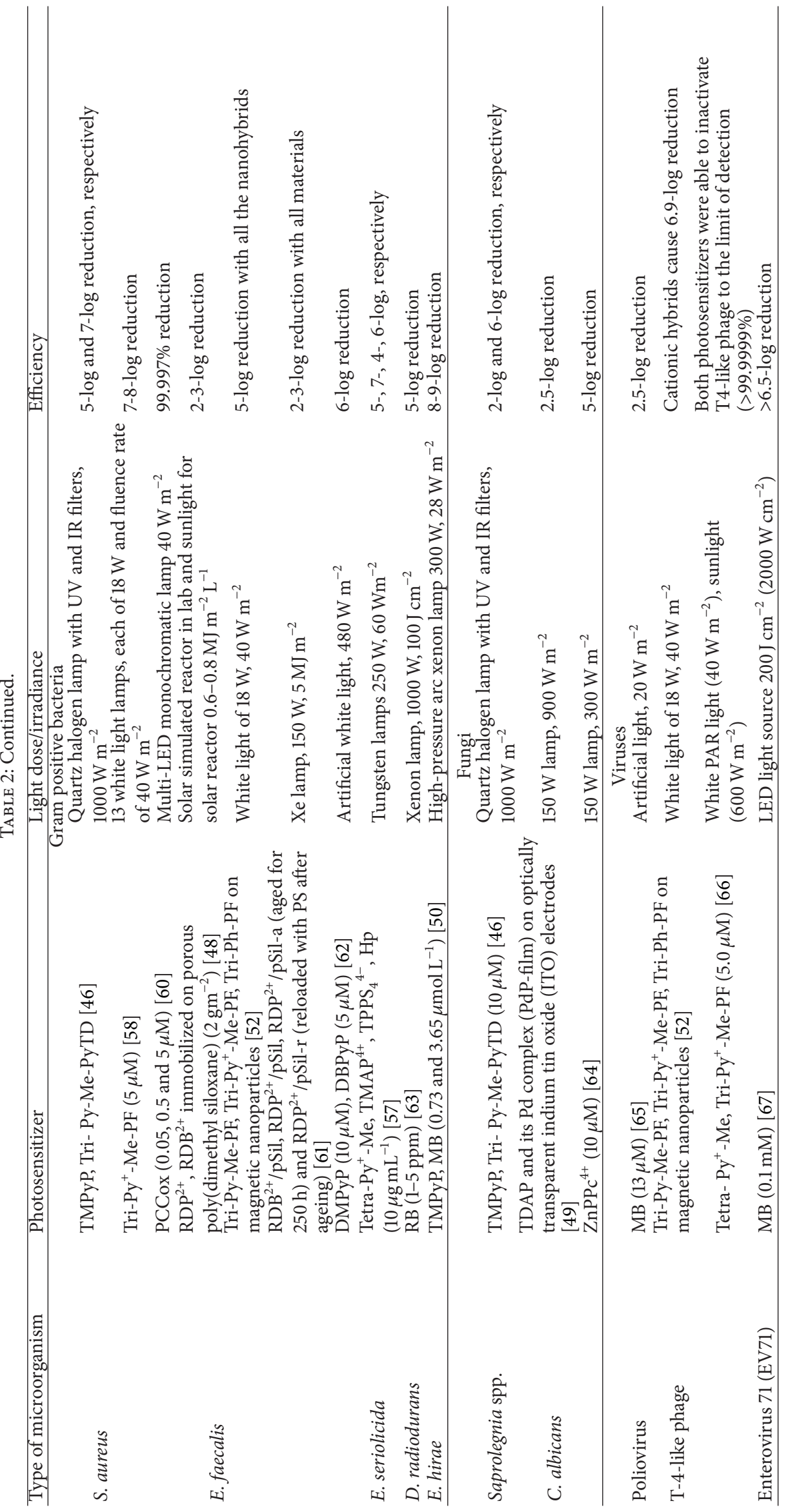


heavy metals. Matilainen and Sillanpää [114] have aptly listed the various organic pollutants in water and photocatalytic decontamination of these pollutants using $\mathrm{TiO}_{2} / \mathrm{UV}$ systems. In recent studies, photoreduction and effective removal of $\mathrm{Cr}(\mathrm{VI})$ using $\mathrm{TiO}_{2}$ on reduced graphene are reported [73]. Magnetic $\mathrm{TiO}_{2}$-graphene [69] composites act as a highly efficient photocatalyst for removal of herbicides from water. They have reported the removal of typical herbicide 2,4dichlorophenoxyacetic acid (2,4-D) from water under simulated solar light irradiation. The use of graphene provides the advantage of using light in the visible range and also adsorption of the contaminants. Aqueous suspension of $\mathrm{TiO}_{2}$ was used for photodegradation of $\mathbf{M B}$ in water [118]. Affam and Chaudhuri [119] successfully carried out photodegradation of pesticides chlorpyrifos, cypermethrin, and chlorothalonil in aqueous solution and propose that $\mathrm{UV} / \mathrm{TiO}_{2} / \mathrm{H}_{2} \mathrm{O}_{2}$ systems can be used for biological treatment.

5.3. Other Environmental Applications. The use of photodynamic process along with decontamination and inactivation in water was also employed to treat infections in fisheries due to invasion by Saprolegnia spp. by in vivo studies [46]. Treatment of rainbow trout (Oncorhynchus mykiss) with submicromolar doses of porphyrin causes $10-13 \%$ of decrease in the infection on fishes and complete remission of infection was induced within 1 week. In a similar study aimed at destruction of fish pathogens, cationic porphyrin was utilized to test against nine pathogenic bacteria found in aquaculture systems [58]. 7-8-log reduction in the bacterial isolates was observed after 60-270 minutes of irradiation. In another interesting scope of application $\mathrm{RB}, \mathrm{MB}$, safranin, and toluidine blue were employed to treat corrosion producing biofilms and planktonic bacteria on oil and gas pipelines [120]. Desulfovibrio vulgaris and Desulfovibrio desulfuricans are well known for aggravating corrosion on steel and other alloys. The studies show that photoinactivation using photosensitizers gave better performance than the commonly used biocide, benzalkonium chloride.

Enterovirus (EV71) spread on solid surface was inactivated by MB-mediated photodynamic action by Wong et al. [66]. No detectable virus was noted when surface-bound EV71 was treated with $\mathrm{MB}$ at a light dose of $50 \mathrm{Jcm}^{-2}$ after 3 days. MB-PDI also prevented EV71 transmission to mice. One-day-old mice that had been in contact with high concentration of EV71 $\left(3 \times 10^{7} \mathrm{pfu}\right)$ for $4 \mathrm{~h}$ exhibited serum conversion, weight loss, and death whereas no infection was observed in mice exposed to same dose of virus after MB-PDT $\left(0.05 \mathrm{mM}, 25 \mathrm{Jcm}^{-2}\right)$. Ismail et al. [121] employed MB-light-activated antimicrobial coatings for disinfecting hospital surfaces. MB with or without gold nanoparticles was coated on silicone polymers. The coated polymers were inoculated with bacterial suspensions of $S$. aureus (MRSA) and irradiated with light intensity of 2,305 lux. After 24 hours illumination, both the MB coatings with and without gold nanoparticles achieved 99.99 and $99.33 \%$ reduction of bacterial population.

Luksiene and Paskeviciute [122] studied the possibility to control microbial contamination of strawberries by $\mathrm{Na}-\mathrm{Chl}$.
Listeria monocytogenes contamination was reduced by $98 \%$ after $30 \mathrm{~min}$ of illumination with visible light at $120 \mathrm{~W} \mathrm{~m}^{-4}$. Naturally occurring yeasts/microfungi and mesophiles were also inhibited by 86 and $97 \%$ thereby increasing strawberries shelf life by 2 days with no negative impact on antioxidant activity and phenols anthocyanins or colour formation.

\section{Limitations}

6.1. Recovery and Reuse. One of the drawbacks of photosensitized water treatment that is often discussed is the recovery of the photosensitizer and its reuse for subsequent treatments. As discussed earlier, sedimentation, coagulation, and filtration processes are time consuming and expensive. It is important to develop methods for easy recovery of photosensitizer. The immobilization of photosensitizers on solid supports like polymers, ITO, and nanocarriers seems promising alternative. However, there are reports on ways to overcome these problems and some have also treated water on immobilized systems on CPC solar reactors [17]. Immobilized systems with maximum photosensitizers loading that improved utilization of available photons and enhanced activity comparable to free photosensitizers are desirable. Nanocarriers are also advantageous in this regard as the problem of limited light penetration is reduced to some extent due to the availability of large surfaces on the nanoparticles [52]. Another factor limiting the reuse of photosensitizers is their degradation due to prolonged exposure to light. $\mathrm{MB}, \mathrm{RB}$, and some porphyrins have been reported to undergo bleaching thereby reducing their photoinactivation efficiencies [81, 84]. Photosensitizers with excellent light stability and capable of absorbing visible light should be employed.

6.2. Resistance of Gram-Negative Bacteria. While $\mathrm{TiO}_{2}$ proves to be efficient in destroying practically both Grampositive and Gram-negative bacteria, organic photosensitizers without positive charge have failed to destroy Gramnegative bacteria $[57,83]$. It is essential to contain a positive moiety on the photosensitizer or the support carrying the sensitizer in order to destabilize the Gram-negative bacteria cell wall (as discussed in Section 4.1).

6.3. Effect of Phototreatment on Nonpathogenic Organisms. Photosensitizer doses, generally at photochemically active doses, are nontoxic for the large majority of biological system. However, it is necessary to evaluate the process for toxic effects on nonpathogenic organisms which are present in water along with pathogenic agents. Fabris et al. [123] have studied the effect of porphyrin doses in the range of $0.1-10 \mu \mathrm{M}$ to protozoan Ciliophora (Colpoda inflata and Tetrahymena thermophila) and the Crustacea Branchiopoda (Artemia franciscana and Daphnia magna). A. franciscana was very resistant to phototreatment whereas $T$. thermophila was resistant to doses up to $3 \mu \mathrm{M}$. On the other hand, C. inflata and D. magna were sensitive to the action of porphyrin. This poses as a potential drawback as D. magna is often selected as a reference standard for assessing the 
TABLE 3: Comparison of features of photosensitizers and photocatalyst.

\begin{tabular}{|c|c|c|}
\hline Feature & Photocatalyst & Organic photosensitizers \\
\hline Light & UV (only $5 \%$ of solar spectrum can be used) $[15,68]$ & Visible light $[52,54]$ \\
\hline ROS & $\begin{array}{l}\text { Hydroxyl radicals }(\bullet \mathrm{OH}) \text { and super oxide anion }\left(\mathrm{O}_{2}{ }^{-}\right) \\
{[1]}\end{array}$ & $\begin{array}{l}\text { Singlet oxygen }\left({ }^{1} \mathrm{O}_{2}\right) \text { and also superoxide anion }\left(\mathrm{O}_{2}{ }^{-}\right) \\
{[23]}\end{array}$ \\
\hline Availability & $\begin{array}{l}\text { Easily available and extensively used for photocatalytic } \\
\text { disinfection and decontamination }\end{array}$ & $\begin{array}{l}\text { Wide range of photosensitizers are available but } \\
\text { require to be synthesized hence increasing the cost [17] }\end{array}$ \\
\hline Stability & Long-term stability & $\begin{array}{l}\text { Some photosensitizers like MB, RB, and Ruthenium } \\
\text { complexes are susceptible to photo bleaching. In some } \\
\text { cases, photodegradation can convert the } \\
\text { photosensitizers into harmless compounds and hence } \\
\text { avoid the separation step [46] }\end{array}$ \\
\hline Immobilized systems & $\begin{array}{l}\text { Immobilized } \mathrm{TiO}_{2} \text { systems work less efficiently than in } \\
\text { suspension [1] }\end{array}$ & $\begin{array}{l}\text { Quantum yield of immobilized photosensitizer is less } \\
\text { than free photosensitizer [8] }\end{array}$ \\
\hline Scope of photocatalysis & $\begin{array}{l}\text { Efficiently capable of decomposing organic and } \\
\text { inorganic pollutants and disinfecting Gram-positive } \\
\text { and Gram-negative bacteria }[14,69]\end{array}$ & $\begin{array}{l}\text { Destruction of Gram-negative bacteria requires } \\
\text { positively charged photosensitizer whereas } \\
\text { Gram-positive bacteria are readily photodisinfected } \\
\text { by anionic and neutral photosensitizers [57]. Very few } \\
\text { reports of decomposition of pollutants are published } \\
{[68,70-73]}\end{array}$ \\
\hline
\end{tabular}

environmental safety. Highlighting similar concerns, Arrojado et al. [58] have also suggested a careful evaluation of environmental impacts of PDT in particular to aquaculture waters. Renovation of the water at each tidal cycle helps to return the nonpathogenic bacteria. Since PDT is not selective for pathogenic bacteria, the nonpathogenic bacteria responsible for turnover of organic matter are also affected. Moreover, another dissolved and particulate matter dissolved in the water also competes for ROS and reduces the efficiency of phototreatment. Therefore, while constructing molecules for photoinactivation purposes, one should also evaluate the toxicity effects to nonpathogenic microorganisms and other larger living bodies in water.

\section{Concluding Remarks and Future Perspectives}

Application of photodynamic action to inactivation and decontamination of water certainly seem to be a promising alternative to the conventional chemical methods of treatment. The numerous selections of photosensitizers render the possibility to explore more into this field. Many semiconductors whose bandwidths lie in the visible region are available. Also, the absorption of $\mathrm{TiO}_{2}$ in the visible region has been the study of many trials by doping $\mathrm{TiO}_{2}$ with other metals. Many enhancements in the semiconductor photocatalysis are being carried out to overcome the present limitations and some are succeeded very well in their attempt.

Metal phthalocyanines and porphyrins and transition metal complexes have proven to be useful in many trials of photoinactivation studies but are still limited to lab scale and pilot plant studies. However, it is desirable to avoid the use of metal centers in water disinfection purposes. Metalfree porphyrin related molecules are also gaining much attention in disinfection studies owing to their long lived triplet excited states and their presence in natural systems. Their use in PDT for cancer treatment is well known. There is much room to investigate the use of porphyrins and related compounds in water disinfection. Pentaphyrins also emerge out as superior photosensitizers due to their enhanced photophysical properties. These expanded porphyrins show strong absorption in the visible region (blue region) and nearinfrared region, hence the possibility of deeper penetration of light into water. They cause several logs of reduction in bacterial count at very low doses of concentration and short period of illumination. The rich chemistry of macrocyclic compounds allows formulating them into photosensitizers with desired absorption maximum and functional groups that are transformable to preferable attach to a support. The methods of immobilization and the different type of supports are already discussed above. Both inorganic and organic photosensitizers are being studied worldwide to improve water treatment processes but the scope in modeling organic sensitizers seems promising. Table 3 compares some features of inorganic and organic sensitizers with respect to factors and their scope in phototreatment.

Photocatalysis also brings about the irreversible oxidation of any unwanted and harmful pollutants in water. However, to carry this phenomenon to actual treatments of wastewater, industrial water, and drinking water treatment, it is necessary to consider the need of pretreatments to water prior to illumination. Villén et al. [17] with their pilot plant experiments show that the costs involved with $\mathrm{TiO}_{2}$ catalysts and $\mathrm{Ru}-$ photosensitizers are comparable. Yet, the cost involved in replacing the conventional water treatment methods and implementing these processes must also be reflected upon.

\section{Conflict of Interests}

The authors declare that there is no conflict of interests regarding the publication of this paper. 


\section{Acknowledgment}

The authors want to thank the Spin-off RISA srl for the sustainability within the Ph.D. "Environmental and Energy Engineering" program.

\section{References}

[1] S. Malato, P. Fernández-Ibáñez, M. I. Maldonado, J. Blanco, and W. Gernjak, "Decontamination and disinfection of water by solar photocatalysis: recent overview and trends," Catalysis Today, vol. 147, no. 1, pp. 1-59, 2009.

[2] S. Baldursson and P. Karanis, "Waterborne transmission of protozoan parasites: review of worldwide outbreaks - an update 2004-2010," Water Research, vol. 45, no. 20, pp. 6603-6614, 2011.

[3] D. Schoenen, "Role of disinfection in suppressing the spread of pathogens with drinking water: possibilities and limitations," Water Research, vol. 36, no. 15, pp. 3874-3888, 2002.

[4] M. Muruganandham, R. P. S. Suri, Sh. Jafari et al., "Recent developments in homogeneous advanced oxidation processes for water and wastewater treatment," International Journal of Photoenergy, vol. 2014, Article ID 821674, 21 pages, 2014.

[5] G. Jori, M. Magaraggia, C. Fabris et al., "Photodynamic inactivation of microbial pathogens: disinfection of water and prevention of water-borne diseases," Journal of Environmental Pathology, Toxicology and Oncology, vol. 30, no. 3, pp. 261-271, 2011.

[6] M. N. Chong, B. Jin, C. W. K. Chow, and C. Saint, "Recent developments in photocatalytic water treatment technology: a review," Water Research, vol. 44, no. 10, pp. 2997-3027, 2010.

[7] T. Zhang, X. Wang, and X. Zhang, "Recent progress in $\mathrm{TiO}_{2}$ mediated solar photocatalysis for industrial wastewater treatment," International Journal of Photoenergy, vol. 2014, Article ID 607954, 12 pages, 2014.

[8] M. C. DeRosa and R. J. Crutchley, "Photosensitized singlet oxygen and its applications," Coordination Chemistry Reviews, vol. 233-234, pp. 351-371, 2002.

[9] Ž. Lukšiene, "New approach to inactivation of harmful and pathogenic microorganisms by photosensitization," Food Technology and Biotechnology, vol. 43, no. 4, pp. 411-418, 2005.

[10] B. D. McGinnis, V. D. Adams, and E. J. Middlebrooks, "Evaluation of methylene blue and riboflavin for the photosensitized degradation of ethylene glycol," Environment International, vol. 25, no. 8, pp. 953-959, 1999.

[11] P. Kluson, M. Drobek, S. Krejcikova et al., "Molecular structure effects in photodegradation of phenol and its chlorinated derivatives with phthalocyanines," Applied Catalysis B: Environmental, vol. 80, no. 3-4, pp. 321-326, 2008.

[12] E. Alves, M. A. F. Faustino, M. G. P. M. S. Neves, Â. Cunha, H. Nadais, and A. Almeida, "Potential applications of porphyrins in photodynamic inactivation beyond the medical scope," Journal of Photochemistry and Photobiology C: Photochemistry Reviews, vol. 22, pp. 34-57, 2015.

[13] A. Mills and S. Le Hunte, "An overview of semiconductor photocatalysis," Journal of Photochemistry and Photobiology A: Chemistry, vol. 108, no. 1, pp. 1-35, 1997.

[14] O. Seven, B. Dindar, S. Aydemir, D. Metin, M. A. Ozinel, and S. Icli, "Solar photocatalytic disinfection of a group of bacteria and fungi aqueous suspensions with $\mathrm{Tio}_{2}, \mathrm{ZnO}$ and sahara desert dust," Journal of Photochemistry and Photobiology A: Chemistry, vol. 165, no. 1-3, pp. 103-107, 2004.
[15] M. Pelaez, N. T. Nolan, S. C. Pillai et al., "A review on the visible light active titanium dioxide photocatalysts for environmental applications," Applied Catalysis B: Environmental, vol. 125, pp. 331-349, 2012.

[16] O. K. Dalrymple, E. Stefanakos, M. A. Trotz, and D. Y. Goswami, "A review of the mechanisms and modeling of photocatalytic disinfection," Applied Catalysis B: Environmental, vol. 98, no. 12, pp. 27-38, 2010.

[17] L. Villén, F. Manjón, D. García-Fresnadillo, and G. Orellana, "Solar water disinfection by photocatalytic singlet oxygen production in heterogeneous medium," Applied Catalysis B: Environmental, vol. 69, no. 1-2, pp. 1-9, 2006.

[18] P. Kluson, M. Drobek, T. Strasak, J. Krysa, M. Karaskova, and J. Rakusan, "Sulphonated phthalocyanines as effective oxidation photocatalysts for visible and UV light regions," Journal of Molecular Catalysis A: Chemical, vol. 272, no. 1-2, pp. 213-219, 2007.

[19] A. K. Benabbou, C. Guillard, S. Pigeot-Rémy et al., "Water disinfection using photosensitizers supported on silica," Journal of Photochemistry and Photobiology A: Chemistry, vol. 219, no. 1, pp. 101-108, 2011.

[20] A. K. Haylett, F. I. McNair, D. McGarvey et al., "Singlet oxygen and superoxide characteristics of a series of novel asymmetric photosensitizers," Cancer Letters, vol. 112, no. 2, pp. 233-238, 1997.

[21] I. J. MacDonald and T. J. Dougherty, "Basic principles of photodynamic therapy," Journal of Porphyrins and Phthalocyanines, vol. 5, no. 2, pp. 105-129, 2001.

[22] Z. Alouini and M. Jemli, "Destruction of helminth eggs by photosensitized porphyrin," Journal of Environmental Monitoring, vol. 3, no. 5, pp. 548-551, 2001.

[23] K.-H. Choi, K.-K. Wang, S.-L. Oh et al., "Singlet oxygen generating nanolayer coatings on NiTi alloy for photodynamic application," Surface and Coatings Technology, vol. 205, no. 1, pp. S62-S67, 2010.

[24] K. Ergaieg, M. Chevanne, J. Cillard, and R. Seux, "Involvement of both Type I and Type II mechanisms in Gram-positive and Gram-negative bacteria photosensitization by a mesosubstituted cationic porphyrin," Solar Energy, vol. 82, no. 12, pp. 1107-1117, 2008.

[25] L. Costa, M. A. F. Faustino, J. P. C. Tomé et al., "Involvement of type I and type II mechanisms on the photoinactivation of non-enveloped DNA and RNA bacteriophages," Journal of Photochemistry and Photobiology B: Biology, vol. 120, pp. 10-16, 2013.

[26] E. F. F. Silva, C. Serpa, J. M. Dąbrowski et al., "Mechanisms of singlet-oxygen and superoxide-ion generation by porphyrins and bacteriochlorins and their implications in photodynamic therapy," Chemistry, vol. 16, no. 30, pp. 9273-9286, 2010.

[27] J. Fenoll, P. Hellín, P. Flores, C. M. Martínez, and S. Navarro, "Photocatalytic degradation of five sulfonylurea herbicides in aqueous semiconductor suspensions under natural sunlight," Chemosphere, vol. 87, no. 8, pp. 954-961, 2012.

[28] T. Daimon, T. Hirakawa, M. Kitazawa, J. Suetake, and Y. Nosaka, "Formation of singlet molecular oxygen associated with the formation of superoxide radicals in aqueous suspensions of $\mathrm{TiO}_{2}$ photocatalysts," Applied Catalysis A: General, vol. 340, no. 2, pp. 169-175, 2008.

[29] R. Konaka, E. Kasahara, W. C. Dunlap, Y. Yamamoto, K. C. Chien, and M. Inoue, "Irradiation of titanium dioxide generates both singlet oxygen and superoxide anion," Free Radical Biology \& Medicine, vol. 27, no. 3-4, pp. 294-300, 1999. 
[30] Z. Malik, J. Hanania, and Y. Nitzan, "New trends in photobiology bactericidal effects of photoactivated porphyrins: an alternative approach to antimicrobial drugs," Journal of Photochemistry and Photobiology, B: Biology, vol. 5, no. 3-4, pp. 281-293, 1990.

[31] S. Ferro, L. Guidolin, G. Tognon, G. Jori, and O. Coppellotti, "Mechanisms involved in the photosensitized inactivation of Acanthamoeba palestinensis trophozoites," Journal of Applied Microbiology, vol. 107, no. 5, pp. 1615-1623, 2009.

[32] G. Bertoloni, F. M. Lauro, G. Cortella, and M. Merchat, "Photosensitizing activity of hematoporphyrin on Staphylococcus aureus cells," Biochimica et Biophysica Acta-General Subjects, vol. 1475, no. 2, pp. 169-174, 2000.

[33] M. R. Hamblin and T. Hasan, "Photodynamic therapy: a new antimicrobial approach to infectious disease?" Photochemical \& Photobiological Sciences, vol. 3, no. 5, pp. 436-450, 2004.

[34] B. Bachmann, J. K. Hopf, B. Lambrecht, and H. Mohr, “Target structures for HIV-1 inactivation by methylene blue and light," Journal of Medical Virology, vol. 47, no. 2, pp. 172-178, 1995.

[35] G. Garcia, V. Sarrazy, V. Sol et al., "DNA photocleavage by porphyrin-polyamine conjugates," Bioorganic \& Medicinal Chemistry, vol. 17, no. 2, pp. 767-776, 2009.

[36] E. D. Quiroga, M. P. Cormick, P. Pons, M. G. Alvarez, and E. N. Durantini, "Mechanistic aspects of the photodynamic inactivation of Candida albicans induced by cationic porphyrin derivatives," European Journal of Medicinal Chemistry, vol. 58, pp. 332-339, 2012.

[37] K. Zupán, M. Egyeki, K. Tóth et al., "Comparison of the efficiency and the specificity of DNA-bound and free cationic porphyrin in photodynamic virus inactivation," Journal of Photochemistry and Photobiology B: Biology, vol. 90, no. 2, pp. 105-112, 2008.

[38] L. Costa, M. A. F. Faustino, M. G. P. M. S. Neves, Â. Cunha, and A. Almeida, "Photodynamic inactivation of mammalian viruses and bacteriophages," Viruses, vol. 4, no. 7, pp. 1034-1074, 2012.

[39] G. Valduga, B. Breda, G. M. Giacometti, G. Jori, and E. Reddi, "Photosensitization of wild and mutant strains of Escherichia coli by meso-tetra ( $N$-methyl-4-pyridyl)porphine," Biochemical and Biophysical Research Communications, vol. 256, no. 1, pp. 84-88, 1999.

[40] A. J. Acher and I. Rosenthal, "Dye sensitized photo oxidation. A new approach to the treatment of organic matter in sewage effluents," Water Research, vol. 11, no. 7, pp. 557-562, 1977.

[41] C. M. B. Carvalho, A. T. P. C. Gomes, S. C. D. Fernandes et al., "Photoinactivation of bacteria in wastewater by porphyrins: bacterial $\beta$-galactosidase activity and leucine-uptake as methods to monitor the process," Journal of Photochemistry and Photobiology B: Biology, vol. 88, no. 2-3, pp. 112-118, 2007.

[42] A. J. Acher and B. J. Juven, "Destruction of coliforms in water and sewage water by dye-sensitized photooxidation," Applied and Environmental Microbiology, vol. 33, no. 5, pp. 1019-1022, 1977.

[43] A. Savino and G. Angeli, "Photodynamic inactivation of E. coli by immobilized or coated dyes on insoluble supports," Water Research, vol. 19, no. 12, pp. 1465-1469, 1985.

[44] A. T. Cooper and D. Y. Goswami, "Evaluation of methylene blue and rose bengal for dye sensitized solar water treatment," Journal of Solar Energy Engineering, Transactions of the ASME, vol. 124, no. 3, pp. 305-310, 2002.

[45] Y. Nitzan and H. Ashkenazi, "Photoinactivation of Deinococcus radiodurans: an unusual gram-positive microorganism," Photochemistry and Photobiology, vol. 69, no. 4, pp. 505-510, 1999.
[46] M. Magaraggia, F. Faccenda, A. Gandolfi, and G. Jori, “Treatment of microbiologically polluted aquaculture waters by a novel photochemical technique of potentially low environmental impact," Journal of Environmental Monitoring, vol. 8, no. 9, pp. 923-931, 2006.

[47] R. Bonnett, M. A. Krysteva, I. G. Lalov, and S. V. Artarsky, "Water disinfection using photosensitizers immobilized on chitosan," Water Research, vol. 40, no. 6, pp. 1269-1275, 2006.

[48] F. Manjón, L. Villén, D. García-Fresnadillo, and G. Orellana, "On the factors influencing the performance of solar reactors for water disinfection with photosensitized singlet oxygen," Environmental Science and Technology, vol. 42, no. 1, pp. 301307, 2008.

[49] M. D. Funes, D. A. Caminos, M. G. Alvarez, F. Fungo, L. A. Otero, and E. N. Durantini, "Photodynamic properties and photoantimicrobial action of electrochemically generated porphyrin polymeric films," Environmental Science and Technology, vol. 43, no. 3, pp. 902-908, 2009.

[50] K. Ergaieg and R. Seux, "A comparative study of the photoinactivation of bacteria by meso-substituted cationic porphyrin, rose Bengal and methylene blue," Desalination, vol. 246, no. 1-3, pp. 353-362, 2009.

[51] A. Tavares, C. M. B. Carvalho, M. A. Faustino et al., "Antimicrobial photodynamic therapy: study of bacterial recovery viability and potential development of resistance after treatment," Marine Drugs, vol. 8, no. 1, pp. 91-105, 2010.

[52] C. M. B. Carvalho, E. Alves, L. Costa et al., "Functional cationic nanomagnet-porphyrin hybrids for the photoinactivation of microorganisms," ACS Nano, vol. 4, no. 12, pp. 7133-7140, 2010.

[53] N. A. Kuznetsova, O. A. Yuzhakova, M. G. Strakhovskaya et al., "New heterogeneous photosensitizers with phthalocyanine molecules covalently linked to aminopropyl silica gel," Journal of Porphyrins and Phthalocyanines, vol. 15, no. 7-8, pp. 718-726, 2011.

[54] P. Parakh, S. Gokulakrishnan, and H. Prakash, "Visible light water disinfection using $\left[\mathrm{Ru}(\mathrm{bpy})_{2}\right.$ (phendione) $]\left(\mathrm{PF}_{6}\right)_{2} \cdot 2 \mathrm{H}_{2} \mathrm{O}$ and $[\mathrm{Ru}$ (phendione) 3$] \mathrm{Cl}_{2 \cdot 2} \mathrm{H}_{2} \mathrm{O}$ complexes and their effective adsorption onto activated carbon," Separation and Purification Technology, vol. 109, pp. 9-17, 2013.

[55] O. L. Osifeko and T. Nyokong, "Applications of lead phthalocyanines embedded in electrospun fibers for the photoinactivation of Escherichia coli in water," Dyes and Pigments, vol. 111, pp. 8-15, 2014.

[56] M. A. di Palma, M. G. Alvarez, A. L. Ochoa, M. E. Milanesio, and E. N. Durantini, "Optimization of cellular uptake of zinc(II) 2,9,16,23-tetrakis[4-( $N$-methylpyridyloxy)]phthalocyanine for maximal photoinactivation of Candida albicans," Fungal Biology, vol. 117, no. 11-12, pp. 744-751, 2013.

[57] M. Merchat, G. Bertolini, P. Giacomini, A. Villanueva, and G. Jori, "Meso-substituted cationic porphyrins as efficient photosensitizers of gram-positive and gram-negative bacteria," Journal of Photochemistry and Photobiology B: Biology, vol. 32, no. 3, pp. 153-157, 1996.

[58] C. Arrojado, C. Pereira, J. P. C. Tomé et al., "Applicability of photodynamic antimicrobial chemotherapy as an alternative to inactivate fish pathogenic bacteria in aquaculture systems," Photochemical \& Photobiological Sciences, vol. 10, no. 10, pp. 1691-1700, 2011.

[59] E. Alves, J. M. M. Rodrigues, M. A. F. Faustino et al., "A new insight on nanomagnet-porphyrin hybrids for photodynamic inactivation of microorganisms," Dyes and Pigments, vol. 110, pp. 80-88, 2014. 
[60] G. Rossi, D. Goi, and C. Comuzzi, “The photodynamic inactivation of Staphylococcus aureus in water using visible light with a new expanded porphyrin," Journal of Water and Health, vol. 10, no. 3, pp. 390-399, 2012.

[61] F. Manjón, M. Santana-Magaña, D. García-Fresnadillo, and G. Orellana, "Singlet oxygen sensitizing materials based on porous silicone: photochemical characterization, effect of dye reloading and application to water disinfection with solar reactors," Photochemical \& Photobiological Sciences, vol. 9, no. 6, pp. 838845, 2010.

[62] V. T. Orlandi, E. Caruso, G. Tettamanti, S. Banfi, and P. Barbieri, "Photoinduced antibacterial activity of two dicationic 5,15diarylporphyrins," Journal of Photochemistry and Photobiology B: Biology, vol. 127, pp. 123-132, 2013.

[63] M. Schäfer, C. Schmitz, R. Facius et al., "Systematic study of parameters influencing the action of Rose Bengal with visible light on bacterial cells: comparison between the biological effect and singlet-oxygen production," Photochemistry and Photobiology, vol. 71, no. 5, pp. 514-523, 2000.

[64] L. Costa, C. M. B. Carvalho, M. A. F. Faustino et al., "Sewage bacteriophage inactivation by cationic porphyrins: influence of light parameters," Photochemical and Photobiological Sciences, vol. 9, no. 8, pp. 1126-1133, 2010.

[65] C. P. Gerba, C. Wallis, and J. L. Melnick, "Application of photodynamic oxidation to the disinfection of tapwater, seawater, and sewage contaminated with poliovirus," Photochemistry and Photobiology, vol. 26, no. 5, pp. 499-504, 1977.

[66] T.-W. Wong, H.-J. Huang, Y.-F. Wang, Y.-P. Lee, C.-C. Huang, and C.-K. Yu, "Methylene blue-mediated photodynamic inactivation as a novel disinfectant of enterovirus 71," Journal of Antimicrobial Chemotherapy, vol. 65, no. 10, Article ID dkq301, pp. 2176-2182, 2010.

[67] D. Gryglik, J. S. Miller, and S. Ledakowicz, "Singlet molecular oxygen application for 2-chlorophenol removal," Journal of Hazardous Materials, vol. 146, no. 3, pp. 502-507, 2007.

[68] D. Li, W. Dong, S. Sun, Z. Shi, and S. Feng, "Photocatalytic degradation of acid chrome blue $\mathrm{K}$ with porphyrin-sensitized $\mathrm{TiO}_{2}$ under visible light," Journal of Physical Chemistry C, vol. 112, no. 38, pp. 14878-14882, 2008.

[69] Y. Tang, G. Zhang, C. Liu, S. Luo, and X. Xu, "Magnetic $\mathrm{TiO}_{2}$ graphene composite as a high-performance and recyclable platform for efficient photocatalytic removal of herbicides from water," Journal of Hazardous Materials, vol. 252-253, pp. 115-122, 2013.

[70] M. Silva, M. J. F. Calvete, N. P. F. Gonçalves et al., “Zinc(II) phthalocyanines immobilized in mesoporous silica Al-MCM41 and their applications in photocatalytic degradation of pesticides," Journal of Hazardous Materials, vol. 233-234, pp. 7988, 2012.

[71] C. Wang, J. Li, G. Mele et al., "Efficient degradation of 4nitrophenol by using functionalized porphyrin- $\mathrm{TiO}_{2}$ photocatalysts under visible irradiation," Applied Catalysis B: Environmental, vol. 76, no. 3-4, pp. 218-226, 2007.

[72] S. Murphy, C. Saurel, A. Morrissey, J. Tobin, M. Oelgemöller, and K. Nolan, "Photocatalytic activity of a porphyrin/ $/ \mathrm{TiO}_{2}$ composite in the degradation of pharmaceuticals," Applied Catalysis B: Environmental, vol. 119-120, pp. 156-165, 2012.

[73] Y. Zhao, D. Zhao, C. Chen, and X. Wang, "Enhanced photoreduction and removal of $\mathrm{Cr}(\mathrm{VI})$ on reduced graphene oxide decorated with $\mathrm{TiO}_{2}$ nanoparticles," Journal of Colloid and Interface Science, vol. 405, pp. 211-217, 2013.
[74] S. A. G. Lambrechts, M. C. G. Aalders, and J. van Marle, "Mechanistic study of the photodynamic inactivation of Candida albicans by a cationic porphyrin," Antimicrobial Agents and Chemotherapy, vol. 49, no. 5, pp. 2026-2034, 2005.

[75] S. Ferro, O. Coppellotti, G. Roncucci, T. B. Amor, and G. Jori, "Photosensitized inactivation of Acanthamoeba palestinensis in the cystic stage," Journal of Applied Microbiology, vol. 101, no. 1, pp. 206-212, 2006.

[76] C. Karunakaran, G. Abiramasundari, P. Gomathisankar, G. Manikandan, and V. Anandi, "Preparation and characterization of $\mathrm{ZnO}-\mathrm{TiO}_{2}$ nanocomposite for photocatalytic disinfection of bacteria and detoxification of cyanide under visible light," Materials Research Bulletin, vol. 46, no. 10, pp. 1586-1592, 2011.

[77] D. Lopes, T. Melo, N. Santos et al., "Evaluation of the interplay among the charge of porphyrinic photosensitizers, lipid oxidation and photoinactivation efficiency in Escherichia coli," Journal of Photochemistry and Photobiology B: Biology, vol. 141, pp. 145-153, 2014.

[78] Z. Smetana, E. Ben-Hur, E. Mendelson, S. Salzberg, P. Wagner, and Z. Malik, "Herpes simplex virus proteins are damaged following photodynamic inactivation with phthalocyanines," Journal of Photochemistry and Photobiology B: Biology, vol. 44, no. 1, pp. 77-83, 1998.

[79] F. Manjón, D. G. Fresnadillo, and G. Orellana, "Water disinfection with $\mathrm{Ru}(\mathrm{II})$ photosensitisers supported on ionic porous silicones," Photochemical \& Photobiological Sciences, vol. 8, no. 7, pp. 926-932, 2009.

[80] Y. Nitzan, M. Gutterman, Z. Malik, and B. Ehrenberg, "Inactivation of gram-negative bacteria by photosensitized porphyrins," Photochemistry and Photobiology, vol. 55, no. 1, pp. 89-96, 1992.

[81] M. Jemli, Z. Alouini, S. Sabbahi, and M. Gueddari, "Destruction of fecal bacteria in wastewater by three photosensitizers," Journal of Environmental Monitoring, vol. 4, no. 4, pp. 511-516, 2002.

[82] D. A. Caminos, M. B. Spesia, and E. N. Durantini, "Photodynamic inactivation of Escherichia coli by novel meso-substituted porphyrins by 4-(3-N,N,N-trimethylammoniumpropoxy) phenyl and 4-(trifluoromethyl) phenyl groups," Photochemical and Photobiological Sciences, vol. 5, no. 1, pp. 56-65, 2006.

[83] M. E. Jiménez-Hernández, F. Manjón, D. García-Fresnadillo, and G. Orellana, "Solar water disinfection by singlet oxygen photogenerated with polymer-supported Ru(II) sensitizers," Solar Energy, vol. 80, no. 10, pp. 1382-1387, 2006.

[84] J. A. Rengifo-Herrera, J. Sanabria, F. Machuca, C. F. Dierolf, C. Pulgarin, and G. Orellana, "A comparison of solar photocatalytic inactivation of waterborne $E$. coli using tris $\left(2,2^{\prime}\right.$ bipyridine)ruthenium(II), Rose bengal, and $\mathrm{TiO}_{2}$," Journal of Solar Energy Engineering, Transactions of the ASME, vol. 129, no. 1, pp. 135-140, 2007.

[85] U. I. Gaya, A. H. Abdullah, M. Z. Hussein, and Z. Zainal, "Photocatalytic removal of 2,4,6-trichlorophenol from water exploiting commercial ZnO powder," Desalination, vol. 263, no. 1-3, pp. 176-182, 2010.

[86] H.-L. Liu and T. C.-K. Yang, "Photocatalytic inactivation of Escherichia coli and Lactobacillus helveticus by $\mathrm{ZnO}$ and $\mathrm{TiO}_{2}$ activated with ultraviolet light," Process Biochemistry, vol. 39, no. 4, pp. 475-481, 2003.

[87] J. Alarcón, S. Ponce, F. P. Delgado, and J. Rodríguez, "Effect of $\gamma$-irradiation on the growth of $\mathrm{ZnO}$ nanorod films for photocatalytic disinfection of contaminated water," Journal of Colloid and Interface Science, vol. 364, no. 1, pp. 49-55, 2011. 
[88] N. Talebian, S. M. Amininezhad, and M. Doudi, "Controllable synthesis of $\mathrm{ZnO}$ nanoparticles and their morphologydependent antibacterial and optical properties," Journal of Photochemistry and Photobiology B: Biology, vol. 120, pp. 66-73, 2013.

[89] M. A. Gondal, M. A. Dastageer, and A. Khalil, "Synthesis of nano- $\mathrm{WO}_{3}$ and its catalytic activity for enhanced antimicrobial process for water purification using laser induced photocatalysis," Catalysis Communications, vol. 11, no. 3, pp. 214-219, 2009.

[90] Z. Fang, J. Yang, Y. Cao et al., "Disinfection of E. coli using visible-light-driven photocatalyst," Procedia Environmental Sciences, vol. 18, pp. 503-508, 2013.

[91] R. van Grieken, J. Marugán, C. Sordo, P. Martínez, and C. Pablos, "Photocatalytic inactivation of bacteria in water using suspended and immobilized silver-TiO ${ }_{2}$," Applied Catalysis B: Environmental, vol. 93, no. 1-2, pp. 112-118, 2009.

[92] C. Karunakaran, V. Rajeswari, and P. Gomathisankar, "Optical, electrical, photocatalytic, and bactericidal properties of microwave synthesized nanocrystalline $\mathrm{Ag}-\mathrm{ZnO}$ and $\mathrm{ZnO}$," Solid State Sciences, vol. 13, no. 5, pp. 923-928, 2011.

[93] C. Karunakaran, A. Vijayabalan, G. Manikandan, and P. Gomathisankar, "Visible light photocatalytic disinfection of bacteria by $\mathrm{Cd}-\mathrm{TiO}_{2}$," Catalysis Communications, vol. 12, no. 9, pp. 826-829, 2011.

[94] Y. Tang, G. Zhang, C. Liu et al., "Magnetic $\mathrm{TiO}_{2}$-graphene composite as a high-performance and recyclable platform for efficient photocatalytic removal of herbicides from water," Journal of Hazardous Materials, vol. 252-253, pp. 115-122, 2013.

[95] P. Fernández-Ibáñez, M. I. Polo-López, S. Malato et al., "Solar photocatalytic disinfection of water using titanium dioxide graphene composites," Chemical Engineering Journal, vol. 261, pp. 36-44, 2015.

[96] A. G. Rincón and C. Pulgarin, "Photocatalytical inactivation of E. coli: effect of (continuous-intermittent) light intensity and of (suspended-fixed) $\mathrm{TiO}_{2}$ concentration," Applied Catalysis B: Environmental, vol. 44, no. 3, pp. 263-284, 2003.

[97] H. Schwegmann, J. Ruppert, and F. H. Frimmel, "Influence of the $\mathrm{pH}$-value on the photocatalytic disinfection of bacteria with $\mathrm{TiO}_{2}$ - explanation by DLVO and XDLVO theory," Water Research, vol. 47, no. 4, pp. 1503-1511, 2013.

[98] Z. Malik, H. Ladan, and Y. Nitzan, "Photodynamic inactivation of Gram-negative bacteria: problems and possible solutions," Journal of Photochemistry and Photobiology B: Biology, vol. 14, no. 3, pp. 262-266, 1992.

[99] A. Acher, E. Fischer, R. Zellingher, and Y. Manor, "Photochemical disinfection of effluents-pilot plant studies," Water Research, vol. 24, no. 7, pp. 837-843, 1990.

[100] A.-G. Rincón and C. Pulgarin, "Effect of pH, inorganic ions, organic matter and $\mathrm{H}_{2} \mathrm{O}_{2}$ on E. coli $\mathrm{K} 12$ photocatalytic inactivation by $\mathrm{TiO}_{2}$ : implications in solar water disinfection," Applied Catalysis B: Environmental, vol. 51, no. 4, pp. 283-302, 2004.

[101] J. A. H. Melián, J. M. D. Rodríguez, A. V. Suárez et al., "The photocatalytic disinfection of urban waste waters," Chemosphere, vol. 41, no. 3, pp. 323-327, 2000.

[102] R. J. Davies-Colley, R. G. Bell, and A. M. Donnison, "Sunlight inactivation of enterococci and fecal coliforms in sewage effluent diluted in seawater," Applied and Environmental Microbiology, vol. 60, no. 6, pp. 2049-2058, 1994.

[103] A. J. Acher, E. Fischer, and Y. Manor, "Sunlight disinfection of domestic effluents for agricultural use," Water Research, vol. 28, no. 5, pp. 1153-1160, 1994.
[104] A. Acher, E. Fischer, R. Turnheim, and Y. Manor, "Ecologically friendly wastewater disinfection techniques," Water Research, vol. 31, no. 6, pp. 1398-1404, 1997.

[105] A.-G. Rincón and C. Pulgarin, "Field solar E. coli inactivation in the absence and presence of $\mathrm{TiO}_{2}$ : is UV solar dose an appropriate parameter for standardization of water solar disinfection?" Solar Energy, vol. 77, no. 5, pp. 635-648, 2004.

[106] C. Sichel, J. Tello, M. de Cara, and P. Fernández-Ibáñez, "Effect of UV solar intensity and dose on the photocatalytic disinfection of bacteria and fungi," Catalysis Today, vol. 129, no. 1-2, pp. 152-160, 2007.

[107] M. Bassiouk, E. Álvarez-Zauco, and V. A. Basiuk, "Adsorption of meso-tetraphenylporphines on thin films of $\mathrm{C}_{60}$ fullerene," Applied Surface Science, vol. 275, pp. 374-383, 2013.

[108] L. Lvova, M. Mastroianni, G. Pomarico et al., "Carbon nanotubes modified with porphyrin units for gaseous phase chemical sensing," Sensors and Actuators B: Chemical, vol. 170, pp. 163-171, 2012.

[109] A. R. McDonald, N. Franssen, G. P. M. van Klink, and G. van Koten, 'Click' silica immobilisation of metallo-porphyrin complexes and their application in epoxidation catalysis," Journal of Organometallic Chemistry, vol. 694, no. 14, pp. 2153-2162, 2009.

[110] F. Nakonechny, A. Pinkus, S. Hai, O. Yehosha, Y. Nitzan, and M. Nisnevitch, "Eradication of gram-positive and gram-negative bacteria by photosensitizers immobilized in polystyrene," Photochemistry and Photobiology, vol. 89, no. 3, pp. 671-678, 2013.

[111] S. Sabbahi, Z. Alouini, L. B. Ayed, M. Jemli, and A. Boudabbous, "Inactivation of faecal bacteria in wastewater by methylene blue and visible light," Desalination and Water Treatment, vol. 20, no. 1-3, pp. 209-219, 2010.

[112] D. Bai, Q. Wang, Y. Song, B. Li, and H. Jing, "Synthesis of cyclic carbonate from epoxide and $\mathrm{CO}_{2}$ catalyzed by magnetic nanoparticle-supported porphyrin," Catalysis Communications, vol. 12, no. 7, pp. 684-688, 2011.

[113] O. Sadeghi, M. M. Amini, M. F. B. Bazargani et al., "Immobilization of metalloporphyrin on functionalized magnetic nanoparticles as a catalyst in oxidation of cyclohexene: novel modified $\mathrm{Fe}_{3} \mathrm{O}_{4}$ nanoparticles with triethoxysilane agent," Journal of Inorganic and Organometallic Polymers and Materials, vol. 22, no. 2, pp. 530-535, 2012.

[114] A. Matilainen and M. Sillanpää, "Removal of natural organic matter from drinking water by advanced oxidation processes," Chemosphere, vol. 80, no. 4, pp. 351-365, 2010.

[115] D. Rubio, J. F. Casanueva, and E. Nebot, "Improving UV seawater disinfection with immobilized $\mathrm{TiO}_{2}$ : study of the viability of photocatalysis (UV254/ $\mathrm{TiO}_{2}$ ) as seawater disinfection technology," Journal of Photochemistry and Photobiology A: Chemistry, vol. 271, pp. 16-23, 2013.

[116] G. Jori, C. Fabris, M. Soncin et al., "Photodynamic therapy in the treatment of microbial infections: basic principles and perspective applications," Lasers in Surgery and Medicine, vol. 38 , no. 5 , pp. $468-481,2006$.

[117] A. J. Acher and A. Elgavish, "The effect of photochemical treatment of water on algal growth," Water Research, vol. 14, no. 5, pp. 539-543, 1980.

[118] J. Wang, C. Li, H. Zhuang, and J. Zhang, "Photocatalytic degradation of methylene blue and inactivation of Gramnegative bacteria by $\mathrm{TiO}_{2}$ nanoparticles in aqueous suspension," Food Control, vol. 34, no. 2, pp. 372-377, 2013. 
[119] A. C. Affam and M. Chaudhuri, "Degradation of pesticides chlorpyrifos, cypermethrin and chlorothalonil in aqueous solution by $\mathrm{TiO}_{2}$ photocatalysis," Journal of Environmental Management, vol. 130, pp. 160-165, 2013.

[120] C. N. Street and A. Gibbs, "Eradication of the corrosion-causing bacterial strains desulfovibrio vulgaris and desulfovibrio desulfuricans in planktonic and biofilm form using photodisinfection," Corrosion Science, vol. 52, no. 4, pp. 1447-1452, 2010.

[121] S. Ismail, S. Perni, J. Pratten, I. Parkin, and M. Wilson, "Efficacy of a novel light-activated antimicrobial coating for disinfecting hospital surfaces," Infection Control and Hospital Epidemiology, vol. 32, no. 11, pp. 1130-1132, 2011.

[122] Z. Luksiene and E. Paskeviciute, "Novel approach to the microbial decontamination of strawberries: chlorophyllin-based photosensitization," Journal of Applied Microbiology, vol. 110, no. 5, pp. 1274-1283, 2011.

[123] C. Fabris, M. Soncin, G. Jori et al., "Effects of a new photoactivatable cationic porphyrin on ciliated protozoa and branchiopod crustaceans, potential components of freshwater ecosystems polluted by pathogenic agents and their vectors," Photochemical \& Photobiological Sciences, vol. 11, no. 2, pp. 294301, 2012. 

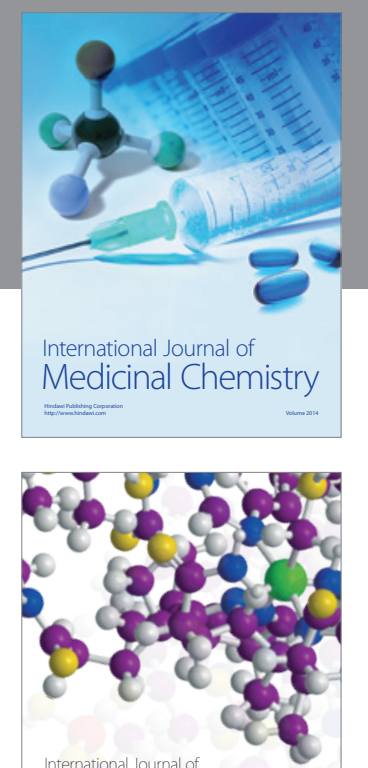

\section{Carbohydrate} Chemistry

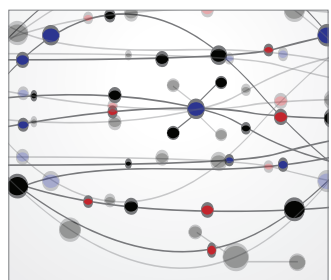

The Scientific World Journal
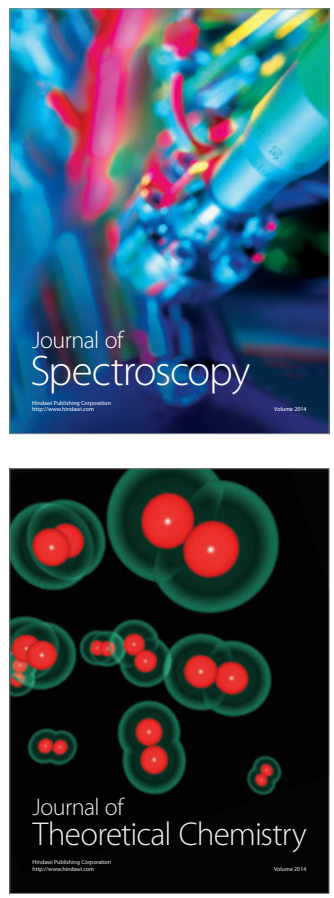
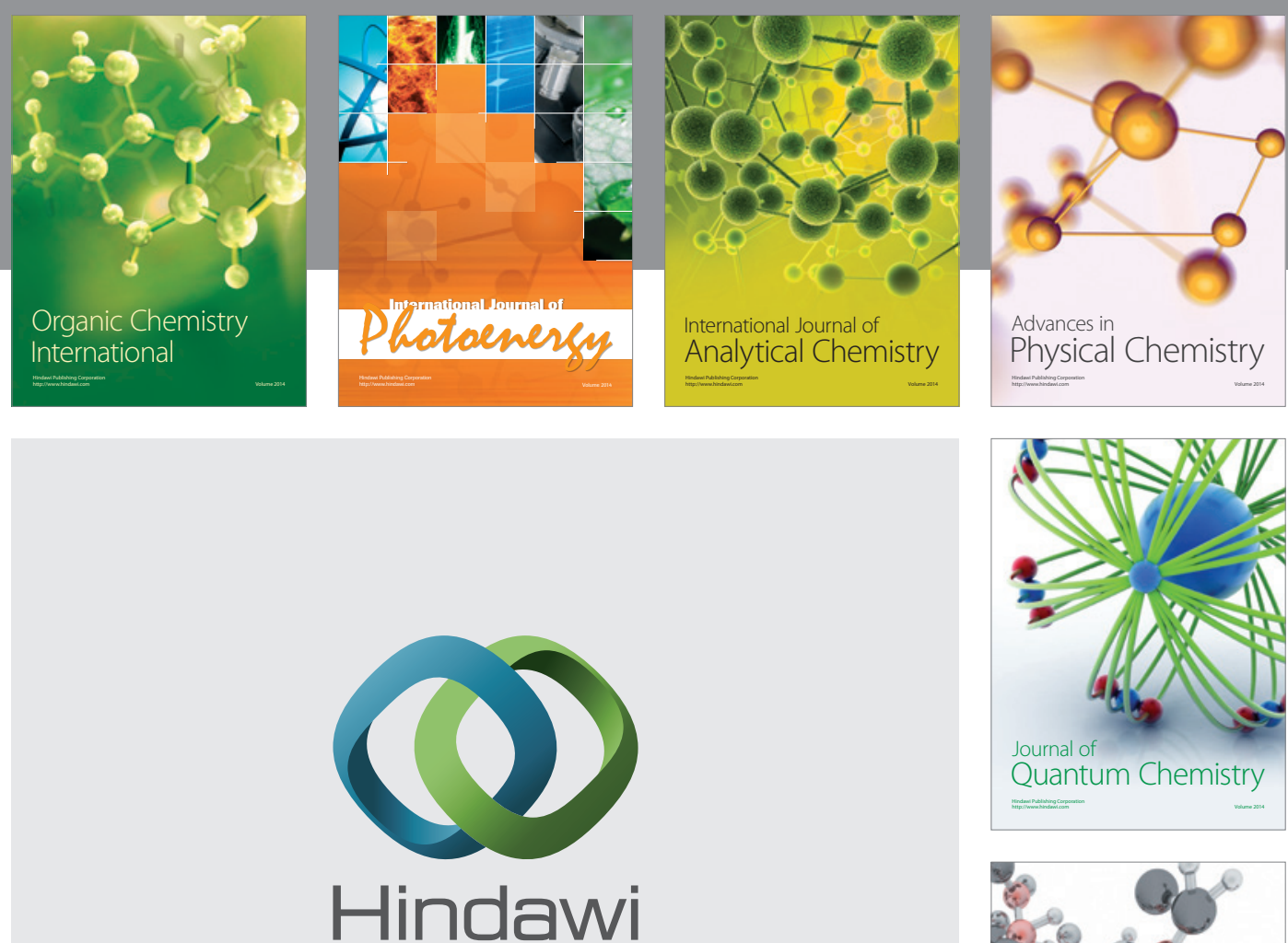

Submit your manuscripts at

http://www.hindawi.com

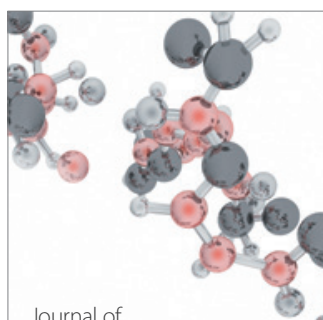

Analytical Methods

in Chemistry

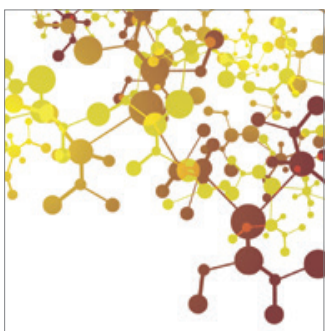

Journal of

Applied Chemistry

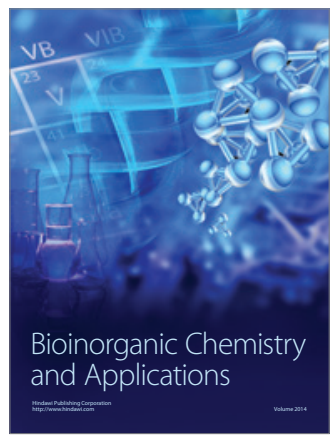

Inorganic Chemistry
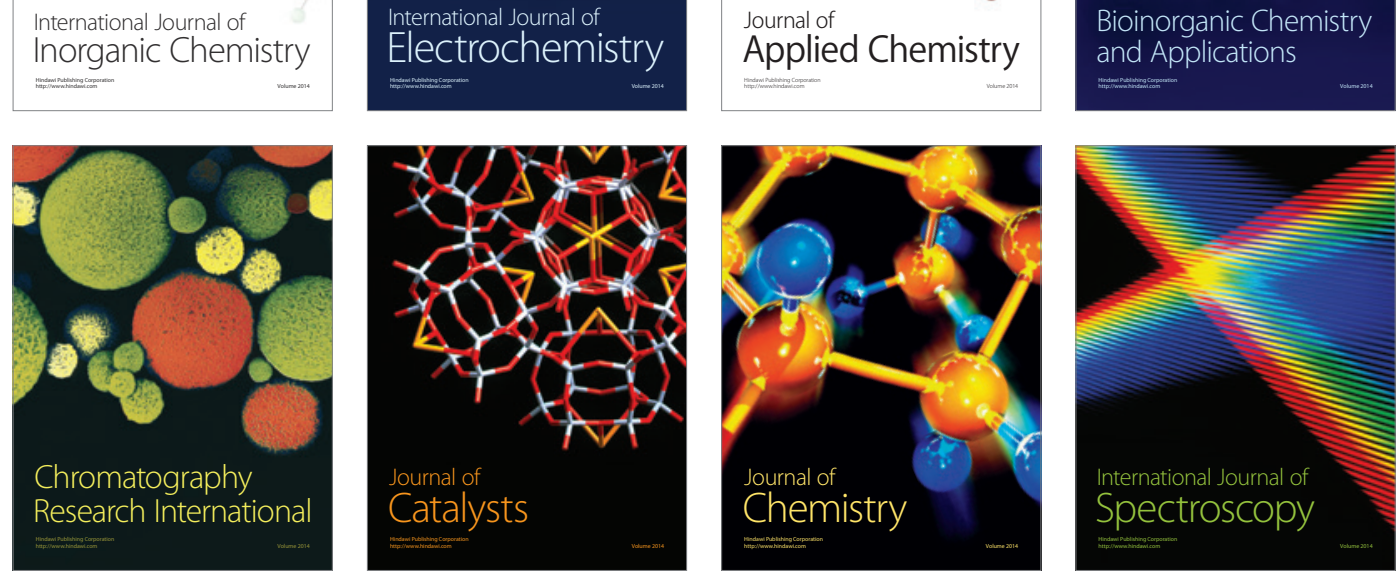